\title{
Differential Expression of Eight Chitinase Genes in Medicago truncatula Roots During Mycorrhiza Formation, Nodulation, and Pathogen Infection
}

\author{
Peter Salzer, ${ }^{1}$ Athos Bonanomi, ${ }^{1}$ Katinka Beyer, ${ }^{1}$ Regina Vögeli-Lange, ${ }^{1}$ Roger A. Aeschbacher, ${ }^{1}$ \\ Jürg Lange, ${ }^{1}$ Andres Wiemken, ${ }^{1}$ Dongjin Kim, ${ }^{2}$ Douglas R. Cook, ${ }^{2}$ and Thomas Boller ${ }^{1}$ \\ ${ }^{1}$ Botanisches Institut der Universität Basel, Hebelstrasse 1, CH-4056 Basel, Switzerland; ${ }^{2}$ Department of \\ Plant Pathology and Microbiology and The Crop Biotechnology Center, Texas A\&M University, College \\ Station 77843-2132, U.S.A. \\ Accepted 9 March 2000.
}

\begin{abstract}
Expression of eight different chitinase genes, representing members of five chitinase classes, was studied in Medicago truncatula roots during formation of arbuscular mycorrhiza with Glomus intraradices, nodulation with Rhizobium meliloti, and pathogen attack by Phytophthora megasperma f. sp. medicaginis, Fusarium solani f. sp. phaseoli (compatible interactions with root rot symptoms), Ascochyta pisi (compatible, symptomless), and $F$. solani f. sp. pisi (incompatible, nonhost interaction). In the compatible plant-pathogen interactions, expression of class I, II, and IV chitinase genes was enhanced. The same genes were induced during nodulation. Transcripts of class I and II chitinase genes accumulated transiently during early stages of the interaction, and transcripts of the class IV chitinase gene accumulated in mature nodules. The pattern of chitinase gene expression in mycorrhizal roots was markedly different: Expression of class I, II, and IV chitinase genes was not enhanced, whereas expression of three class III chitinase genes, with almost no basal expression, was strongly induced. Two of these three (Mtchitinase III-2 and Mtchitinase III-3) were not induced at all in interactions with pathogens and rhizobia. Thus, the expression of two mycorrhiza-specific class III chitinase genes can be considered a hallmark for the establishment of arbuscular mycorrhiza in Medicago truncatula.
\end{abstract}

Additional keywords: chalcone synthase, trehalase.

Corresponding author: Peter Salzer, Botanisches Institut der Universität Basel, Hebelstrasse 1, CH-4056 Basel, Switzerland; Telephone: +41 61 267 2318; Fax: +41 61267 2330; E-mail: Peter.Salzer@unibas.ch

Nucleotide and/or amino acid sequence data have been submitted to the National Center for Biotechnology Information (NCBI) Genome Survey Sequence data base (GSSdb) as the following accession numbers: Mtchitinase I, AF167322; Mtchitinase II, AF167323; Mtchitinase III-1, AF167324; Mtchitinase III-2, AF167325; Mtchitinase III-3, AF167326; Mtchitinase III-4, AF167327; Mtchitinase IV, AF167328; Mtchitinase V, AF167329. Sequence data for trehalase and ubiquitin were deposited at the EMBL gene bank as accession number AJ238651 for the trehalase gene, AJ245511 for the ubiquitin gene fragment of Medicago truncatula, and AJ245512 for the ubiquitin gene fragment of Glomus mosseae.
Medicago truncatula is a diploid autogamous legume with a short generation time that can be readily transformed with Agrobacterium tumefaciens (Cook et al. 1997). While the well-known model plant Arabidopsis thaliana only interacts antagonistically with microorganisms and has no known mutualistic symbionts, $M$. truncatula, like most legumes, has the potential to entertain two different mutualistic symbioses in its roots, namely, with fungi involved in arbuscular mycorrhiza (AM) (Harrison and Dixon 1994; Salzer et al. 1999) and with rhizobia involved in nodule formation and nitrogen fixation (Cook et al. 1995, 1997). This allows comparisons between different types of plant-symbiont and plant-pathogen interactions, and $M$. truncatula has therefore been proposed as a model plant to study interactions with microorganisms (Cook 1999).

Chitinases have received particular attention in plantmicrobe interactions and have been the subject of many reviews (Boller 1987; Collinge et al. 1993; Meins et al. 1992, 1994). They are grouped into six classes (I-VI): each class is characterized by a common primary structure of the protein (Collinge et al. 1993; Meins et al. 1992, 1994; Melchers et al. 1994) and by consensus sequences (Levorson and Chlan 1997). Chitinases are hydrolytic enzymes (E.C. 3.2.1.14) that are able to cleave $\beta$-1,4-glycosidic bonds between $N$-acetyl glucosamine residues of chitin. This polysaccharide is a primary structural component of the wall of all true fungi, including fungi involved in AM and ectomycorrhiza (EM), as well as many pathogens, indicating that chitinases are important in plant-fungal interactions (see Boller 1987).

The role of chitinases as part of the inducible plant defense response is well documented (Boller 1987; Collinge et al. 1993). For example, class I and V chitinases were shown to have anti-fungal activity in vitro (Arlorio et al. 1992; Mauch et al. 1988; Melchers et al. 1994; Schlumbaum et al. 1986), and tobacco plants constitutively expressing class I chitinases showed increased resistance to the pathogenic fungus Rhizoctonia solani (Broglie et al. 1991; Vierheilig et al. 1993).

The role of chitinases in mutualistic symbioses is less clear. With regard to the nodule symbiosis, chitinases have been shown to differentially cleave Nod factors, and they have therefore been proposed to modulate the activity of these key morphogenetic signals during symbiotic development 
(Schultze et al. 1998; Staehelin et al. 1994a, 1994b). In EM, plant chitinases may function to degrade chitin fragments, released from walls of the symbiotic fungus, that would otherwise elicit host defense responses (Salzer et al. 1997a, 1997b). Interestingly, growth of fungi involved in EM and AM formation were not inhibited by class I chitinases that were antifungal against pathogens (Arlorio et al. 1991; Salzer et al. 1997b; Vierheilig et al. 1993). Taken together, these results suggest differential effects of chitinases in symbiotic versus pathogenic interactions.

Generally, chitinase activity is at a low level in plants but is induced in response to various stimuli, e.g., the phytohormone ethylene (Chen and Bleeker 1995; Shinshi et al. 1995; Siefert et al. 1994; Xie et al. 1996), salicylic acid (Jung et al. 1993; Margis-Pinheiro et al. 1994), virus infections (Lawton et al. 1992; Ohme-Takagi et al. 1998; Payne et al. 1990), and various pathogenic microorganisms (Kästner et al. 1998; Mohr et al. 1998; Münch-Garthoff et al. 1997; Vad et al. 1993). With respect to the mutualistic AM symbiosis, studied in leek infected with $G$. mosseae, chitinase activity increased during early stages of the interaction and was suppressed in later stages (Spanu et al. 1989). Similar results have been obtained in the alfalfa-G. intraradices interaction (Volpin et al. 1994).

There are indications that the induction of various isoforms of chitinases is differentially regulated at the level of gene expression (Collinge et al. 1993; Meins et al. 1992). The same stimulus may trigger up-regulation of certain chitinase isoforms and down-regulation of others. In tobacco, for example, two acidic isoforms of chitinase were induced and expression of a basic chitinase gene suppressed by the AM fungus Glomus intraradices (David et al. 1998; Dumas-Gaudot et al. 1992).

Here, we establish $M$. truncatula as a model for the functional analysis of chitinases in roots interacting with pathogenic fungi, rhizobia, and mycorrhizal fungi. We provide a comprehensive picture of the expression of individual chitinase genes in these different plant-microbe interactions, and we describe the induction of two class III chitinase genes in $M$. truncatula as a hallmark for the establishment of the AM symbiosis.

\section{RESULTS}

\section{Infection of $M$. truncatula roots with pathogenic fungi.}

As a basis for a comparison of chitinase gene expression between $M$. truncatula roots colonized by mutualistic symbionts and pathogenic fungi, we first established pathosystems for $M$. truncatula roots consisting of compatible interactions with strong root rot symptoms, compatible, symptomless biotrophic interactions, and incompatible nonhost interactions. Inoculation of $M$. truncatula roots with Fusarium solani f. sp. phaseoli, the causal agent of dry root rot of bean (VögeliLange et al. 1995), produced necrotic lesions on roots of $M$. truncatula, accompanied by the collapse of cortical cells. Within 5 days, the infection spread along the primary and secondary roots (Fig. 1A) and the fungus formed typical, sickleshaped macro-conidia within the root tissue (Fig. 2A). Infection with Phytophthora megasperma f. sp. medicaginis, the causal agent of alfalfa root rot, also caused browning of the lateral roots (Fig. 1B). In the infected areas of the root, clusters of young oogonia with paragyn antheridia (Fig. 2B) as well as sporangia (Fig. 2C) were formed, indicating that this fungus completed its life cycle within M. truncatula roots. Ascochyta pisi caused no obvious disease symptoms 5 days after inoculation (Fig. 1D). However, microscopic examination of the roots revealed that this fungus colonized the rhizodermis and root hairs and formed chains of chlamydospores within the plant tissue (Fig. 2D, E). In contrast to the compatible interactions described above, Fusarium solani f. sp. pisi caused no disease symptoms (Fig. 1C) and failed to penetrate the roots. Although inoculated chlamydospores attached to the root surface, fungal structures could not be detected within the root tissue 5 days after inoculation (not shown).

\section{Cloning of chitinase genes.}

To obtain chitinase genes from $M$. truncatula, we compared DNA sequences for over 80 plant, fungal, animal, and bacterial genes (data not shown). Conserved regions for each of the subclasses that contained plant chitinase genes were identified and used to design degenerate oligonucleotide primers for polymerase chain reaction (PCR; Table 1). Following amplification of genomic DNA from $M$. truncatula, DNA sequencing of the cloned amplification products confirmed that we had cloned PCR fragments for eight distinct chitinase genes, representing five chitinase subclasses. One gene each was identified for subclasses I, II, IV, and V, while four distinct genes were identified for subclass III (Fig. 3). By means of Southern blot analysis, we determined that each of these eight genes did not cross-hybridize with any of the other chitinase genes (data not shown). We recovered the corresponding full-length genomic clones from an M. truncatula BAC (bacterial artificial chromosome) genomic library (Nam et al. 1999), as indicated in Table 1.

\section{Use of ubiquitin genes and a trehalase gene as controls in RT-PCR.}

To compare gene expression by reverse transcription (RT)PCR between noninfected roots and roots infected by fungi, it is necessary to use an internal standard to monitor the amount of cDNA derived from the plant. For this purpose we selected the ubiquitin gene, which had been demonstrated to be constitutively expressed in pea, and therefore seemed to be useful as an internal control (Albrecht et al. 1998). To design primers specific for $M$. truncatula ubiquitin, $M$. truncatula and Glomus mosseae genomic DNA was amplified by PCR with primers corresponding to conserved regions of ubiquitin (Heidstra et al. 1997). Sequencing of the cloned fragments revealed $77 \%$ homology at the nucleotide level (Fig. 4A) and 96\% homology at the protein level (data not shown) between the $M$. truncatula and $G$. mosseae genes. Using sequence alignment, we designed oligonucleotide primers against regions of the $M$. truncatula gene that diverged considerably from the G. mosseae gene (Fig. 4A). These primers readily amplified the ubiquitin template from total $M$. truncatula genomic DNA, but not from genomic DNA of the fungal symbiont $G$. intraradices, or from the pathogenic fungi Phytophthora megasperma f. sp. medicaginis, Fusarium solani $\mathrm{f}$. sp. phaseoli, or Fusarium solani f. sp. pisi (Fig. 4B). Although an amplification product was obtained from A. pisi DNA, the PCR product had a larger size and thus was easily distinguished from $M$. truncatula upon agarose gel electrophoresis (Fig. 4B). Similar results were obtained by RT-PCR with 
RNA from $M$. truncatula and the different fungi (data not shown).

Furthermore, there is a potential risk of genomic DNA contaminations in RT-PCR studies, although the RNA preparations are routinely treated with DNase I before RT. To visualize potential contaminations by genomic DNA, we used a trehalase gene from $M$. truncatula that contained an intron, and we designed primers spanning the intron.

\section{Induction of chitinase gene expression by pathogenic fungi.}

In the compatible interactions with $F$. solani f. sp. phaseoli and $P$. megasperma f. sp. medicaginis, which led to strong disease symptoms, expression of Mtchitinase I, II, III-1, and IV genes was enhanced, with the strongest increase occurring in expression of Mtchitinase IV (Fig. 5). In the compatible biotrophic interaction with $A$. pisi, expression of Mtchitinase I and III-1 was enhanced. In addition, Mtchitinase III-4 was expressed at a low level (Fig. 5). On the other hand, in the incompatible interaction with $F$. solani f. sp. pisi, only expression of Mtchitinase IV was stimulated (Fig. 5).

\section{Induction of different chitinase genes}

during early and late stages of nodule formation.

In contrast to infection by pathogenic fungi, formation of mutualistic symbioses in $M$. truncatula is a process that demands several weeks. Three days after inoculation with $R h i$ zobium meliloti, nodule meristems were apparent; after 10 days, white nodules have developed; and after 20 days, the entire root system harbored red, functional nodules. Chitinase gene expression differed at various stages of the nodulation process. At early stages, about 3 days after inoculation, expression of Mtchitinase I and II was transiently increased (Fig. 6). At later stages, expression of these genes was hardly detectable but transcripts of Mtchitinase IV chitinase strongly accumulated in nodules, particularly in the most mature ones. In addition, expression of Mtchitinase III-4 was slightly induced (Fig. 6).

\section{Expression of class III chitinase genes in AM formed by $G$. intraradices on roots of $M$. truncatula.}

To perform studies on gene expression in early and later stages of the mycorrhiza formation, we employed two different inoculation procedures. For early interactions, the inoculum was directly dropped on the roots to provide contact with the fungus from the beginning of the experiment. To obtain even colonization of the whole root system in later stages, the inoculum was mixed with the substratum before the seedlings were planted.

In early stages, before arbuscules were formed, the $M$. truncatula roots showed only very little response to $G$. intraradices. Expression of Mtchitinase II, III-1, and IV, as well as expression of a chalcone synthase gene, was only slightly enhanced, and expression of Mtchitinase III-2, III-3, and III-4 could not be detected (Fig. 7). In fully mycorrhizal roots at a later stage, however, where about $60 \%$ of the root length was colonized (in $1 \mathrm{~cm}$ of colonized roots up to 100 arbuscules and 10 vesicles were found), expression of these three class III chitinase genes, namely, Mtchitinase III-2, III-3, and III-4, was strongly induced (Fig. 8). In contrast, expression levels of Mtchitinase I, II, III-1, and IV, which were increased in re- sponse to pathogenic fungi and rhizobia, were similar or somewhat lower than in nonmycorrhizal controls (Fig. 8).

\section{DISCUSSION}

By establishing four different pathosystems for $M$. truncatula roots, in conjunction with the already well-described mutualistic symbioses with rhizobia and AM fungi, we are able to provide a comprehensive picture of chitinase gene expression in one plant in response to various kinds of interactions with microorganisms. Our first surprising result is that chitinase gene expression during nodulation with rhizobia is more related to interactions with pathogenic fungi than to formation of AM. Even more unexpected is our finding that chitinase gene expression in mycorrhizal roots is different from that in all the other types of interactions and involves a mycorrhiza-specific expression of two class III chitinase genes.

Chitinase gene expression in response to pathogenic fungi.

Induction of chitinase activity and of genes encoding various isoforms of chitinase has been extensively studied in plant-pathogen interactions, and the expression patterns we observed with our newly established pathosystems for $M$. truncatula roots corresponded to what was known from other plant pathogen interactions (Table 2). For example, the induction of Mtchitinase I, II, III-1, and IV in response to the different Fusarium solani strains closely resembled their induction in broad bean (Mohr et al. 1998), and induced expression of a class I chitinase gene in response to A. pisi was also found in pea (Vad et al. 1993). On the other hand, Mtchitinase III-4 was differentially expressed in response to virulent and avirulent fungi. This gene was only expressed in interactions with those pathogenic fungi that caused no disease symptoms in M. truncatula roots.

\section{Differential induction of chitinases in M. truncatula during early and late stages of nodulation.}

Expression of different chitinase genes occurred in M. truncatula during early and later stages of the nodule formation with $R$. meliloti. During early stages of the symbiosis, when first nodule primordia became obvious, the expression of Mtchitinase I and II transiently increased. Because these same chitinase genes were induced in $M$. truncatula during infection by pathogenic fungi, and class I and II chitinase genes are commonly induced by pathogenic fungi (Table 2), it seems plausible that induction of these genes during nodulation may represent a transient defense response to compatible $R$. meliloti. In fact, Vasse et al. (1993) documented the accumulation of the pathogenesis-related $(\mathrm{PR})$ proteins $\mathrm{P}$ and $\mathrm{Q}$ (corresponding to class II chitinases) during the alfalfa- $R$. meliloti symbiosis, and determined that these epitopes localized to necrotic cells that also contained arrested rhizobial infections, reminiscent of a defense response. The transient character of the chitinase expression in $M$. truncatula roots probably reflected the transient action of Nod factors, which can also act as elicitors. In roots of soybean, for example, Nod factors from Bradyrhizobium japonicum were sufficient to induce enhanced chitinase activity (Xie et al. 1999).

In contrast to the transient expression of class I and II chitinases, class IV chitinase transcripts were detected as early 
as 1 day post inoculation, and continued to increase throughout the 20-day time course of nodulation. Moreover, transcript levels were elevated both in nodules and in areas of the roots that lacked nodules. Staehelin et al. (1992) determined that, within soybean nodules, chitinase was localized in the nodule endodermis. Thus, in soybean nodules the chitinase activity is unlikely to interact directly with the bacterial symbiont, but may instead provide a preformed barrier to fungal infection.

Interestingly, expression of class III chitinase genes in $M$. truncatula during nodulation differed from that of other legumes. While in Sesbania rostrata a class III chitinase is supposed to be a early nodulin (Goormachtig et al. 1998) and in Vicia faba two proteins (Nvf32-A1, Nvf32-A2) with some sequence homology to class III chitinases accumulated during nodule formation (Perlick et al. 1996), in no stage of the interaction with $R$. meliloti did strong induction of a class III chitinase gene occur in $M$. truncatula roots.
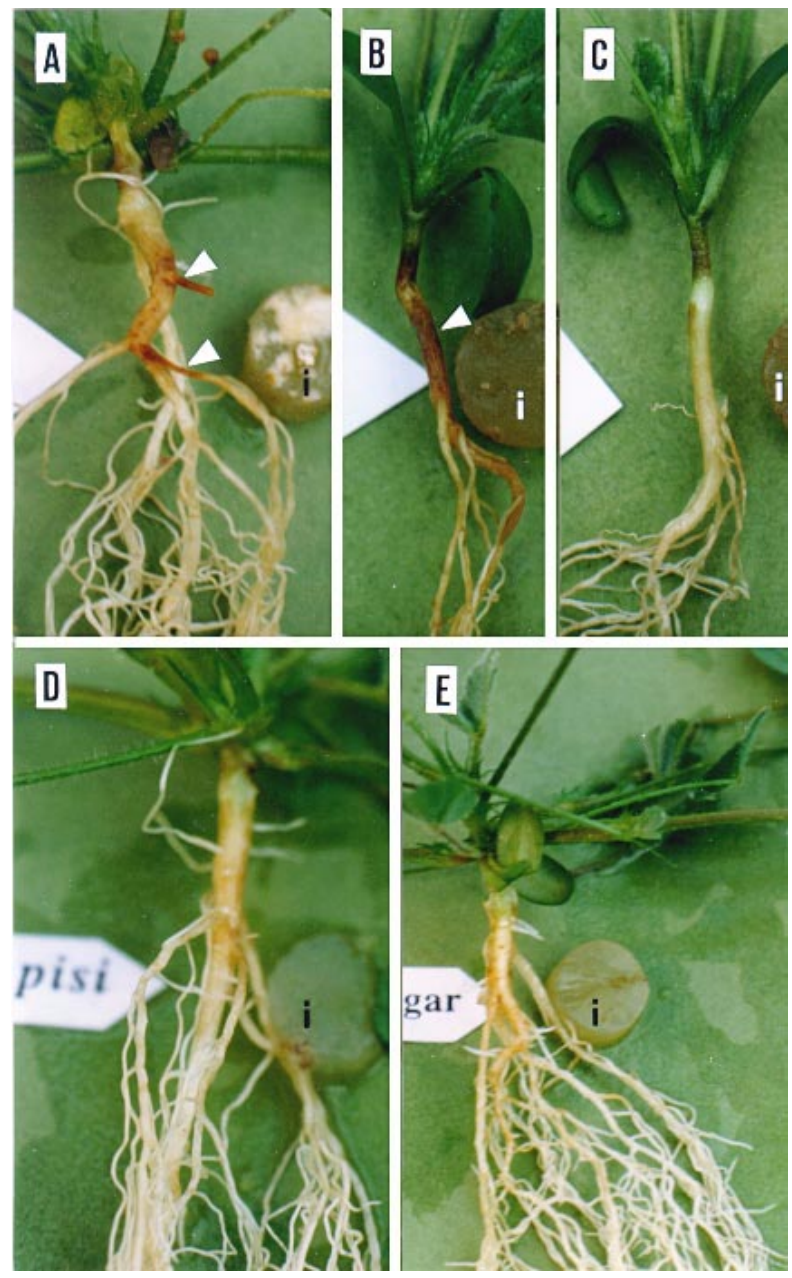

Fig. 1. Macroscopic disease symptoms of Medicago truncatula roots infected with pathogenic fungi. V8-agar disks with fungal inoculum were brought into contact with the root surface of 3- to 5-week-old $M$. truncatula plants. Five days after inoculation with (A) Fusarium solani f. sp. phaseoli and (B) Phytophthora megasperma f. sp. medicaginis, browning of roots became obvious (indicated by arrowheads). No browning was observed after inoculation with (D) Ascochyta pisi, (C) F. solani f. sp. pisi, and (E) V8 agar disks without fungus. Similar observations were made in five independent plants in two independent experimental series for each of the pathogenic fungi.
Expression of mycorrhiza-specific class III chitinase genes in AM of M. truncatula.

Chitinase expression in mycorrhizal $M$. truncatula roots was completely different from that in roots infected with rhizobia or pathogenic fungi (Fig. 9). In roots colonized by $G$. intraradices, expression of Mtchitinase III-2, III-3, and III-4 was strongly induced in mature mycorrhizae. The expression of Mtchitinase III-2 and III-3 was mycorrhiza specific, because they were not expressed in any other type of interaction. On the other hand, expression of those chitinase genes that are induced during pathogen attack or nodulation, namely, Mtchitinase I, II, and IV, was not increased in functioning mycorrhizae. These mycorrhiza-specific changes in chitinase gene expression are unexpected, because numerous previous studies had indicated that similar genes, proteins, and signal transduction pathways were activated during AM formation and nodulation (Albrecht et al. 1998; Frühling et al. 1997; Wyss et al. 1990; Xie et al. 1999). Apparently, to maintain a functional AM association with $G$. intraradices, the expression of a unique set of chitinase genes is required: In AM of $M$. truncatula with $G$. intraradices all class III chitinase genes are expressed, and the expression of the defense-related Mtchitinase I, II, and IV is kept at a low, basal level or even suppressed (Fig. 9).

The function of the class III-2 and III-3 chitinases, which are specifically induced in AM of M. truncatula, is unclear. However, it is conceivable that expression of these class III chitinases is involved in suppression of plant defense reactions in the later stages of the AM as observed in bean, leek, and alfalfa (Lambais and Mehdy 1993; Spanu et al. 1989; Volpin et al. 1994). The chitinases, which are induced by the AM fungus, could cleave the fungal elicitors and, in turn, attenuate defense responses. The following arguments support this hypothesis: (i) in various cell culture systems, e.g., tomato (Felix et al. 1993), rice (Inui et al. 1996, 1997), alfalfa (Savouré et al. 1997), and spruce (Hebe et al. 1999), $\mathrm{N}$ acetyl glucosamine oligomers were demonstrated to induce defense responses; (ii) chitin-related elicitors were also released from walls of the AM fungus $G$. intraradices (Salzer and Boller 2000); (iii) chitinases from spruce cells were able to cleave elicitors from various EM fungi in the same way as chitin elicitors (Salzer et al. 1997a, 1997b); and (iv) treatment of EM elicitors with chitinases reduced their ability to induce defense responses in plant cells (Salzer et al. 1997a, 1997b).

\section{MATERIALS AND METHODS}

\section{Plant culture, synthesis of AM, and infection with rhizobia and pathogenic fungi.}

The Medicago truncatula cv. Jemalong strain A 17 was germinated on agar and grown in Terra Green as previously described (Salzer et al. 1999), with the exception that the plants were continuously fertilized with B\&D medium (Broughton and John 1979) containing $0.5 \mathrm{mM}$ inorganic potassium phosphates and $2 \mathrm{mM} \mathrm{KNO}_{3}$. These culture conditions were continued after inoculation of the plants with all the different microorganisms.

Culture of the AM-forming fungus Glomus intraradices Schenk \& Smith, inoculation, and synthesis of AM were performed as previously described (Salzer et al. 1999). 

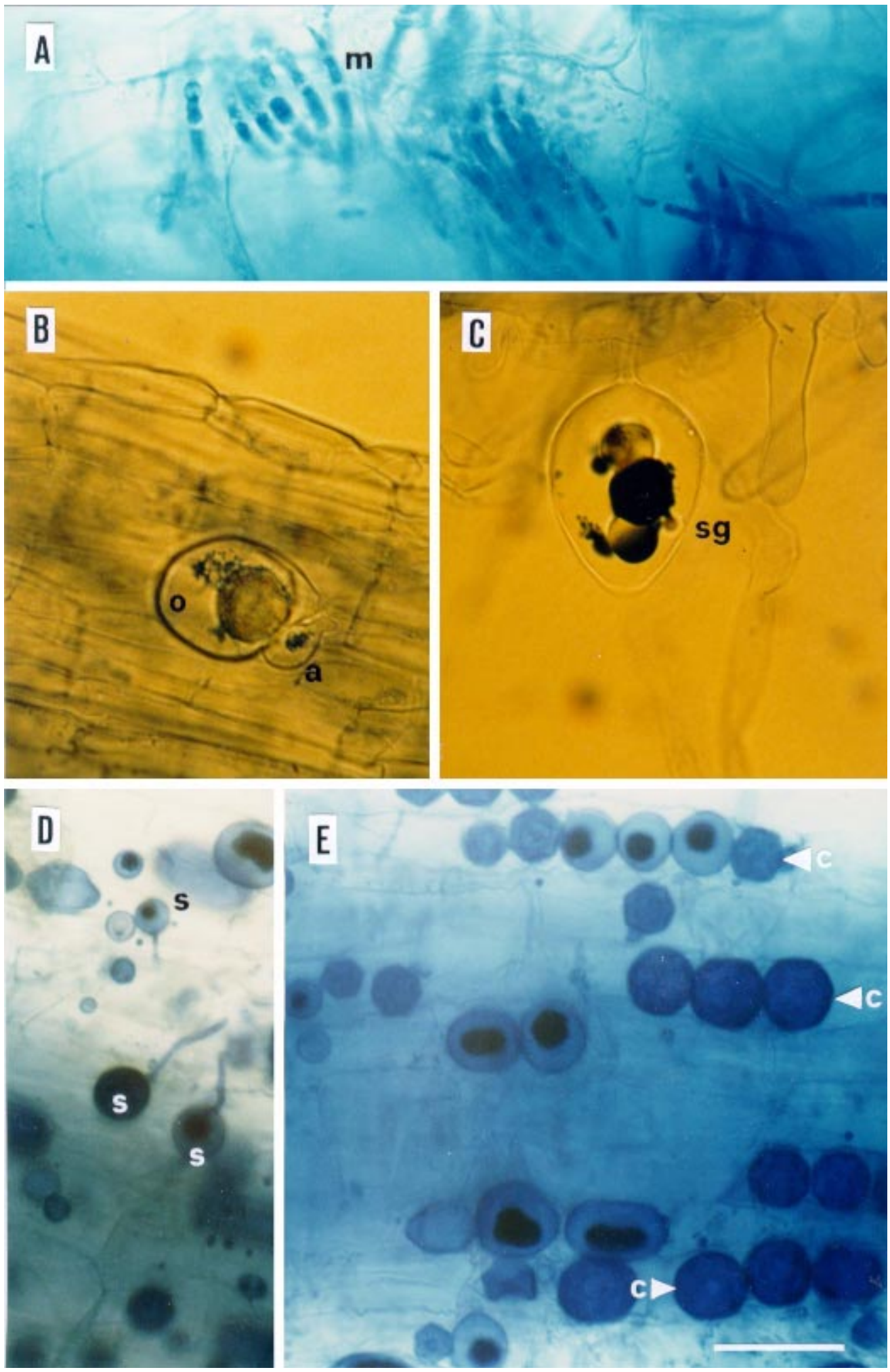

Fig. 2. Reproductive structures of pathogenic fungi in Medicago truncatula roots. A, Sickle-shaped macroconidia (m) of Fusarium solani f. sp. phaseoli within M. truncatula root tissue. B, Oogonium (o) with a paragyn antheridium (a), and (C) an ovoid sporangium (sg) of Phytophthora megasperma f. sp. medicaginis protruding from root surface of M. truncatula. D, Germinating spores (s) of Ascochyta pisi on surface and chains of chlamydospores (c) within rhizodermal cells of $M$. truncatula. Structures shown were observed 5 days after inoculation. Bar $=20 \mu \mathrm{m}$. With each fungus, similar observations were made on five separately cultured plants in two independent experiments. 
For nodulation, $3 \mathrm{ml}$ of a Rhizobium meliloti (strain 1021, kindly provided by P. Curioni, ETH Zürich, Switzerland) suspension was added to 6- to 10 -week-old plants. Before inoculation, the rhizobia had been cultured at $27^{\circ} \mathrm{C}$ for 3 days in succinate minimal medium (Schmidt et al. 1992). Control plants were mock inoculated with $3 \mathrm{ml}$ of the bacterial culture medium.

The following pathogenic fungi were used to inoculate 3- to 6-week-old M. truncatula plants: Fusarium solani f. sp. phaseoli (strain W-8), F. solani f. sp. pisi (teleomorph Nectria haematococca mating population VI strain 77-104), Phytophthora megasperma f. sp. medicaginis (kindly provided by the Novartis fungal pathogen collection, Basel, Switzerland) and Ascochyta pisi Lib. (from the house collection of the Botanical Institute, Basel). Before inoculation, the fungi were grown on V8 agar at room temperature for 12 days. Then, agar disks $(0.5 \mathrm{~cm}$ in diameter) were cut from the margins of the fungal mycelium and placed close to the root. In control experiments, plants were mock inoculated with V8 agar disks without fungi.

All procedures described above were performed under sterile conditions.

\section{Infection analyses.}

For microscopic studies, roots were cleared with $10 \% \mathrm{KOH}$ and stained with trypan blue in lactophenol (Phillips and

Table 1. Degenerate primer sequences used for polymerase chain reaction cloning of Medicago truncatula genes ${ }^{\mathrm{a}}$

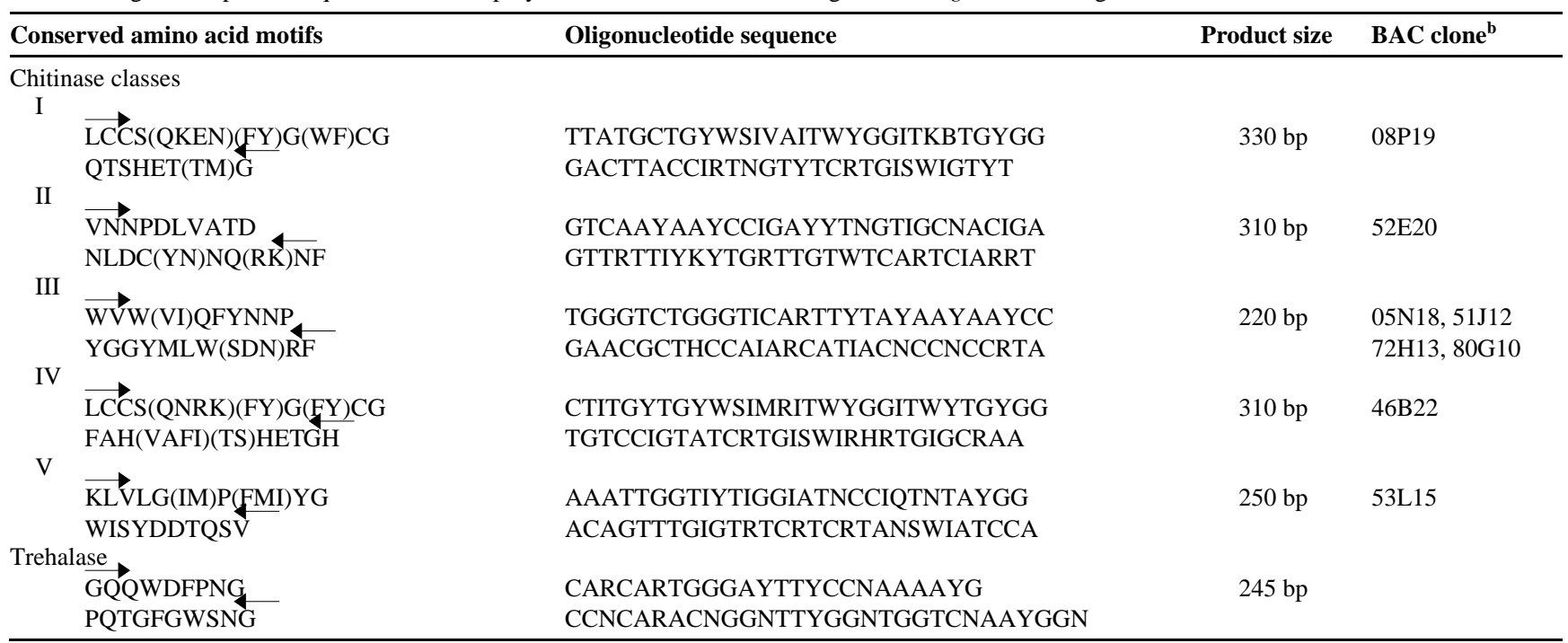

${ }^{\mathrm{a}}$ Degenerate nucleotides: $\mathrm{R}=\mathrm{A}$ or $\mathrm{G} ; \mathrm{Y}=\mathrm{C}$ or $\mathrm{T} ; \mathrm{B}=\operatorname{not} \mathrm{A} ; \mathrm{H}=\operatorname{not} \mathrm{G} ; \mathrm{N}=\mathrm{A}, \mathrm{C}, \mathrm{G}$ or T; $\mathrm{W}=\mathrm{A}$ or T; $\mathrm{S}=\mathrm{G}$ or $\mathrm{C} ; \mathrm{K}=\mathrm{G}$ or T; M $=\mathrm{A}$ or $\mathrm{C} . \mathrm{Amino}$ acids in parentheses represent variation at a single position.

${ }^{\mathrm{b}}$ Bacterial artificial chromosome.

\section{Mtchitinase I}

15 '-TTATGCTGTTCGAAGTTTGGGTTTTGCGGATCAACCGGCGACTACTGTGG

51 TGATGGTTGTCAGAGTCAATGTAGTGGAAGCAGCGGTGACCTTGGTAGCC

101 TCATCTCAAGGGACACCTTCAACAATATGCTCAAGCACCGTGACGACAGT

151 GGGTGTCAGGGAAAAAGATTGTACACCTATGATGCTTTCATCTCAGCTGC

201 CAAGGCTTTCCCCAACTTTGGCAATAATGGAGATACTGCAACTAAAAAAA

251 GAGAGATTGCTGCTTTCTTGGGTCAGACCTGCCACGAAACGATAGGTAAG

Mtchitinase II

15 '-GTCAACAATCCGGATTTGGTGGCTACGGACCCAACTGTATCATTCAAGAC

51 AGCCATATGGTTTTGGATGACCCCTCAAGGAAACAAGCCATCAAGCCATG

101 ATGTGATTATTGGAAGATGGACGCCATCGGTGTCAGACAGGTCAGCCGGA

151 ATGGGTCCCCGGATACGGCGTGATCACCAACATAATCAACGGTGGGCTCGA

151 CGGGTCCCGGATACGGCGTGATCACCAACATAATCAACGGGGGCTCGA

201 ATGCGGGCATGGACAGGATGCTCGAGTTAATGATCGGATCGGGTTTTATA

251 GAAGGTATTGTCAAATATTGGGAGTGA

Mtchitinase III-1

15 '-TGGGTCTGGGTGCAGTTTTATAACAACCCTGGTGCTTGTAACTTTGTTTC

51 AAACAATCCAACTAGCTTTAAGAATTCATGGAGCCAGTGGATCAATTCTA

101 TGTCTACTAAAAAGGTTTTCGTTGGACTTCCTGCTAGCTCATCTAATGCA

151 GCTCCAAGTGGTGGTTTTGTGGAAGCACAGGATCTTATAAATCAATTGCT

201 GCCTATTGTTAAGCCTTCACCTAAGGATGGGGGTGTCATGCTCTGGGÄGC

Mtchitinase

15 '-TGGGTCTGGGTGCAGTTTTACAATAACCCTGAATGTGATATAGTGAAAG 51 CGAGGTTAACCGCTTGTTGGATTCGTGGAAGCGATGGACAAAAGTCGTTA 101 ACGTCGGGAAAAGTGTTTTGGGGATTGCCCGCTTCCCCTGCAAGCAGCAG 151 ATAATGGCTATGTTCCAGCTTGATTTGTTGTGTGAGATTGTAGTTCCTGT 201 TTTAAGGATATCGCGTAACGACGGCGGCGGAGTCATGTTCTGGTAGCGTT $251 \quad \mathrm{C}-3 \cdot 251$

\section{Mtchitinase III-3}

$155^{\prime}$-TGGGTCTGGGTGCAATTTIATAACAACCCTCCTTGTCAATACAATCCTGG 51 TGAAATTAGCAACCTTGAAGATGCATGGAAGCAGTGGACATCAGGTATCC 101 CTGCAAACAAGATATTCTTGGGGTTACCTGCTTCCCAGAGGCTGCAGGCA 151 GTGGCTTCATTCCTGCTACTGATCTTACTTCCACTGTGCTTCCAGCTATT 201 AAAGGTTCTGCTAAAGACGGCGGCGTCATGCTCTGGAAGCGTTC-3'244 Mtchitinase $111-4$

$15{ }^{\prime}$-TGGGTCTGGGTGCAGTTTTATAACAACCCTCCTTGTCAATACAACCCTGA 51 TGCATTTATGAACTTCGAAGATGCGTGGAAGCAGTGGACATCAGGTATCC 101 CTGCAAACAAGATATTCTTAGGGTTACCTGCTTCTCCAACGGCTGCAGGA 151 AGCGGTTTTATTTCCGCAGATGATCTTACCTCTACTGTACTTCCAGTTAT 201 TAAAGGTTCTTCCAAAGACGGTGGTGTCATGTTCTGGAAGCGTTC-3' 245

Mtchitinase IV

15 -CTGTGTTGCACGAAGTATGGGTATTGCGGTAATGGTGATTCCATATTGTGG 51 CACAGGGTGCAAACAAGGTCCTTGTTATGCAGGCCAAACACCACCAAGTT 101 TGCCTAACAATGATGCTAATGTGGCTGACATCCTTACACAAGATTTCTTC 151 AATCGTATAATTGATCAAGCTGATTCTAGTTGTGCAGGAAAGAACTTCTA 151 AATCGTATAATTGATCAAGCTGATTCTAGTTGTGCAGGAAAGAACTTCTA 251 GGTCTGGATCTTTGGATGACTCCAAACGTGAGGTTGCTGCTGCTTTTGCC 301. CACACCAGCCACGATACCGGACA-3' 323

\section{Mtchitinase $\mathrm{V}$}

15 -AAATTGGTGTTGGGGATCCCGATTTATGGGAAGAGTTGGAAGCTTCAGGA 51 TCCGAATGTGCATGGAATCGGGGCACCGAATGTTGGGCCGGGTCCTGGGG 101 TTGATGGTGGAATGGCGTATTTTCAAGTTGTGGATTTTAATAAACAAATG 151 GGTGCAAAAGTGGTGTATGACAAGGAGACCGGATCGGTTTATTCATATAG

201 TGGGAGTATTTGGATTTCATACGATGACACCCAAACTGT-3' 239

Fig. 3. Nucleotide sequence of chitinase gene fragments amplified from a Medicago truncatula genomic bacterial artificial chromosome (BAC) library (Nam et al. 1999) by polymerase chain reaction with degenerate oligonucleotide primers, then cloned and sequenced. Arrows indic ate primer sequences used for semiquantitative reverse transcription-PCR and their orientation. 
Hayman 1970). The degree of colonization with G. intraradices was determined according to Giovanetti and Mosse (1980). Infection with pathogenic fungi was examined on longitudinal sections of the infected root area with a Zeiss Axioplan microscope under bright-field conditions. Pictures were taken with a Zeiss M 35 F camera coupled to a Zeiss MC 63 light detection system with Kodak EPJ 320T films.

\section{mRNA expression studies.}

Plant material (100 mg fresh weight) was homogenized in liquid nitrogen and RNA extracted with a Plant RNeasy Extraction Kit (Qiagen, Basel, Switzerland) with RLT-lysis buffer, and a 3 -min incubation at $56^{\circ} \mathrm{C}$. Then, the RNA preparation was treated with DNase I (Message Clean Kit; GeneHunter, Nashville, TN), following the manufacturer's instructions. Reverse transcription of $1 \mu \mathrm{g}$ of RNA was performed with the Reverse Transcription System (Promega, Madison, WI) in a total volume of $20 \mu \mathrm{l}$ with oligo $(\mathrm{dT})_{15}$ primers at $42^{\circ} \mathrm{C}$ for $15 \mathrm{~min}$. Semiquantitative PCR was carried out with a dilution series $(1: 1,1: 4,1: 16,1: 64,1: 256)$ of the template cDNA. One microliter of cDNA was used per $20 \mu \mathrm{l}$ of PCR mix, containing $2 \mu \mathrm{l}$ of $10 \times$ PCR buffer (Amersham Pharmacia Biotech Europe, Dübendorf, Switzerland, 1.6 $\mu \mathrm{l}$ of dNTPs (2.5 mM concentrations of each; Amersham Pharmacia), 0.1

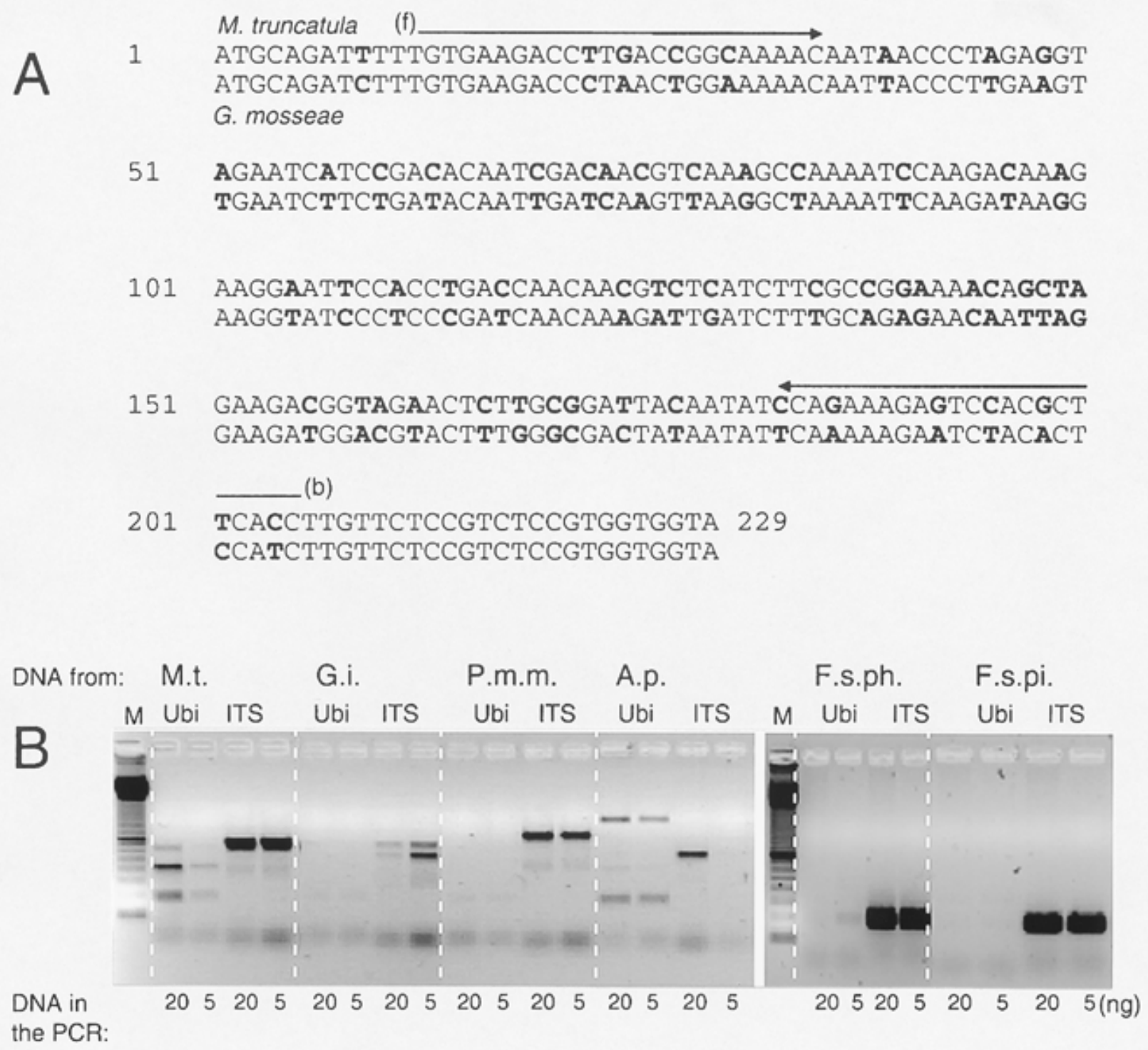

Fig. 4. Specific detection of ubiquitin from Medicago truncatula. A, Alignment of nucleotide sequences from ubiquitin from M. truncatula (upper line) and Glomus mosseae genomic DNA (lower line). Different nucleotides at corresponding positions are typed in bold. Arrows indicate position and orientation of M. truncatula-specific primers designed for reverse transcription-polymerase chain reaction (RT-PCR); (f) indicates their forward, (b) their backward orientation. B, PCR on genomic DNA with M. truncatula-specific primers. PCR only amplified ubiquitin fragments from M. truncatula (M.t.), not from G. intraradices (G.i.), Phytophthora megasperma f. sp. medicaginis (P.m.m.), Fusarium solani f. sp. phaseoli (F.s.ph.), or F. solani f. sp. pisi (F.s.pi.). Fragments amplified from Ascochyta pisi differed in size from those of $M$. truncatula, allowing recognition of M. truncatula ubiquitin by different size. Size differences of $100 \mathrm{bp}$ are indicated by bands of the 100-bp ladder, which served as marker (M). PCR products obtained with ITS1/ITS4 primer combinations served as positive control for presence of fungal or plant DNA. With the exception of the Fusarium spp., where ITS1/ITS4 primer combinations specific for Fusarium spp. were used, primers described by Heidstra et al. (1997) were employed. The same results were obtained in two independent experiments. 
A Chitinase genes of
M. truncatula:
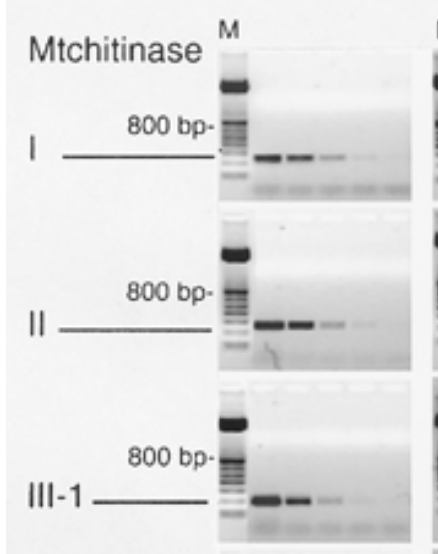

III-2

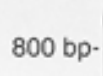

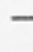
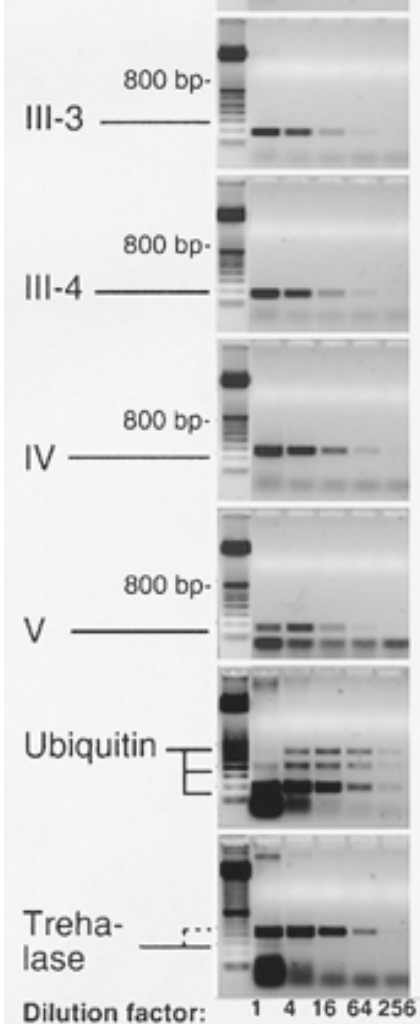

B M. truncatula roots inoculated with pathogenic fungi:

\begin{tabular}{c|c|c|c} 
V8-agar & F.s. ph. P.m. m. & A.p. & F.s. pi. \\
not colonized & colonized with symptoms & $\begin{array}{l}\text { colonized no } \\
\text { no symptoms }\end{array}$
\end{tabular} \mid $\begin{aligned} & \text { not colonized, } \\
& \text { symptoms }\end{aligned}$

symptoms
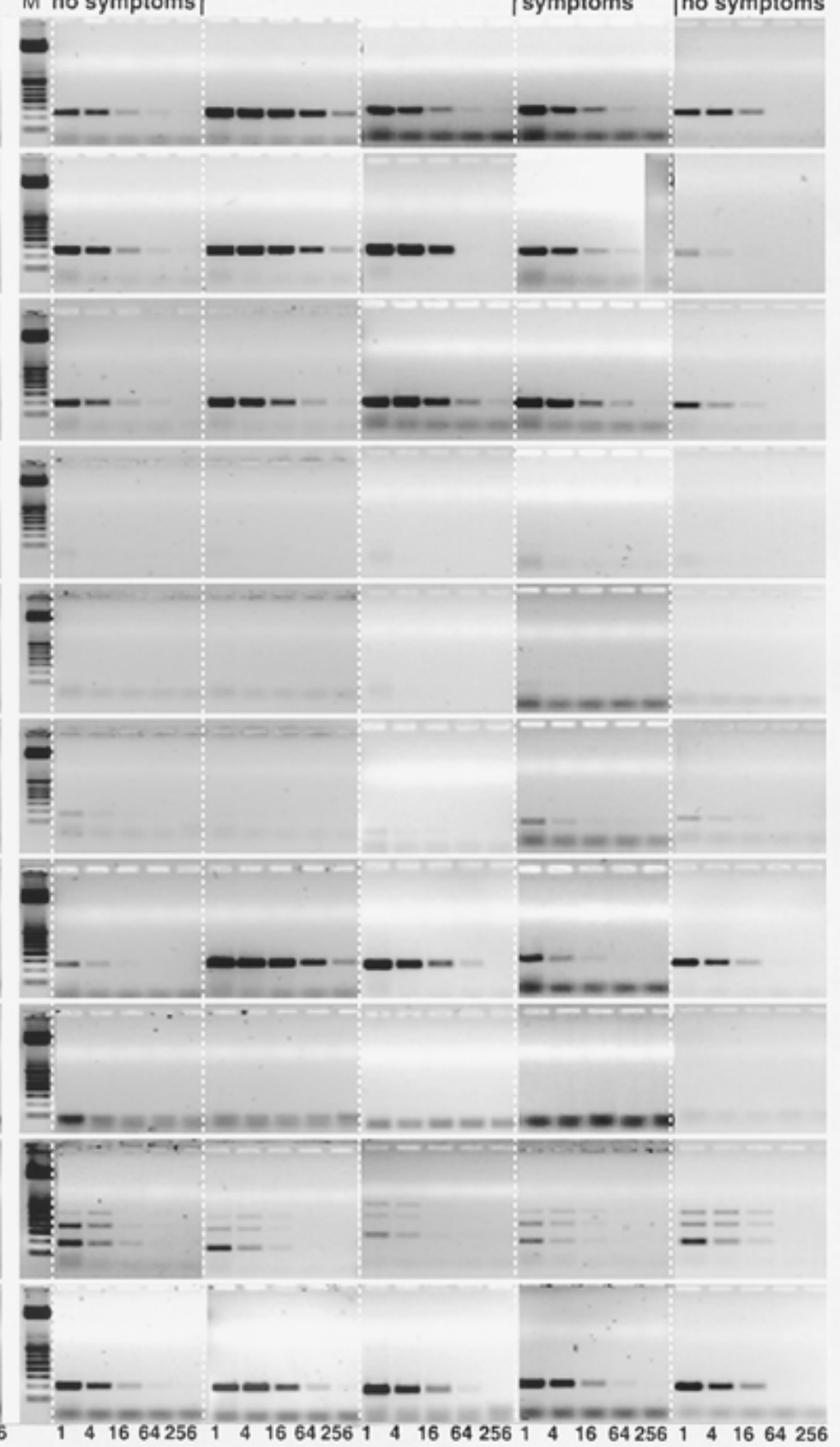

Fig. 5. Chitinase gene expression in plant-pathogen interactions. A, Semiquantitative polymerase chain reaction (PCR) performed with a dilution series of genomic DNA from Medicago truncatula with Mtchitinase primers, M. truncatula-specific ubiquitin primers, and intron-spanning trehalase primers. Dilution factors 1, 4, 16, 64, and 256 correspond to 5, 1.25, 0.31, 0.08, and 0.02 ng of DNA subjected to PCR. As marker (M) a 100-bp ladder was used with its 800-bp fragment more intensively stained. Position of labeling indicates size of expected PCR products. For trehalase, PCR product obtained with intron-containing genomic DNA is labeled by a dashed line; corresponding RT-PCR product obtained with cDNA by a plain line. Signals on the gel bottoms are due to primer dimer formation. B, Semiquantitative RT-PCR was performed with a dilution series of cDNA obtained from RNA extracted from M. truncatula roots 5 days after inoculation with Fusarium solani f. sp. phaseoli (F.s.ph.), Phytophthora megasperma f. sp. medicaginis (P.m.m.), Ascochyta pisi (A.p.), or F. solani f. sp. pisi (F.s.pi.), or mock inoculation with V8 agar. Mtchitinase I and III-1 are induced in all the compatible interactions, whereas strong induction of Mtchitinase II occurred only in response to F. solani f. sp. phaseoli. Slight expression of Mtchitinase III-4 was only apparent in roots inoculated with V8 agar or challenged with the avirulent fungi. Similar intensity of $M$. truncatula-specific ubiquitin signal indicates equal introduction of cDNA into the PCR. Exclusive appearance of a 245-bp trehalase PCR product confirms that no genomic DNA was amplified in the PCR. Identical results were obtained in two independent experimental series. 
Roots of $M$. truncatula infected with Rhizobium meliloti:

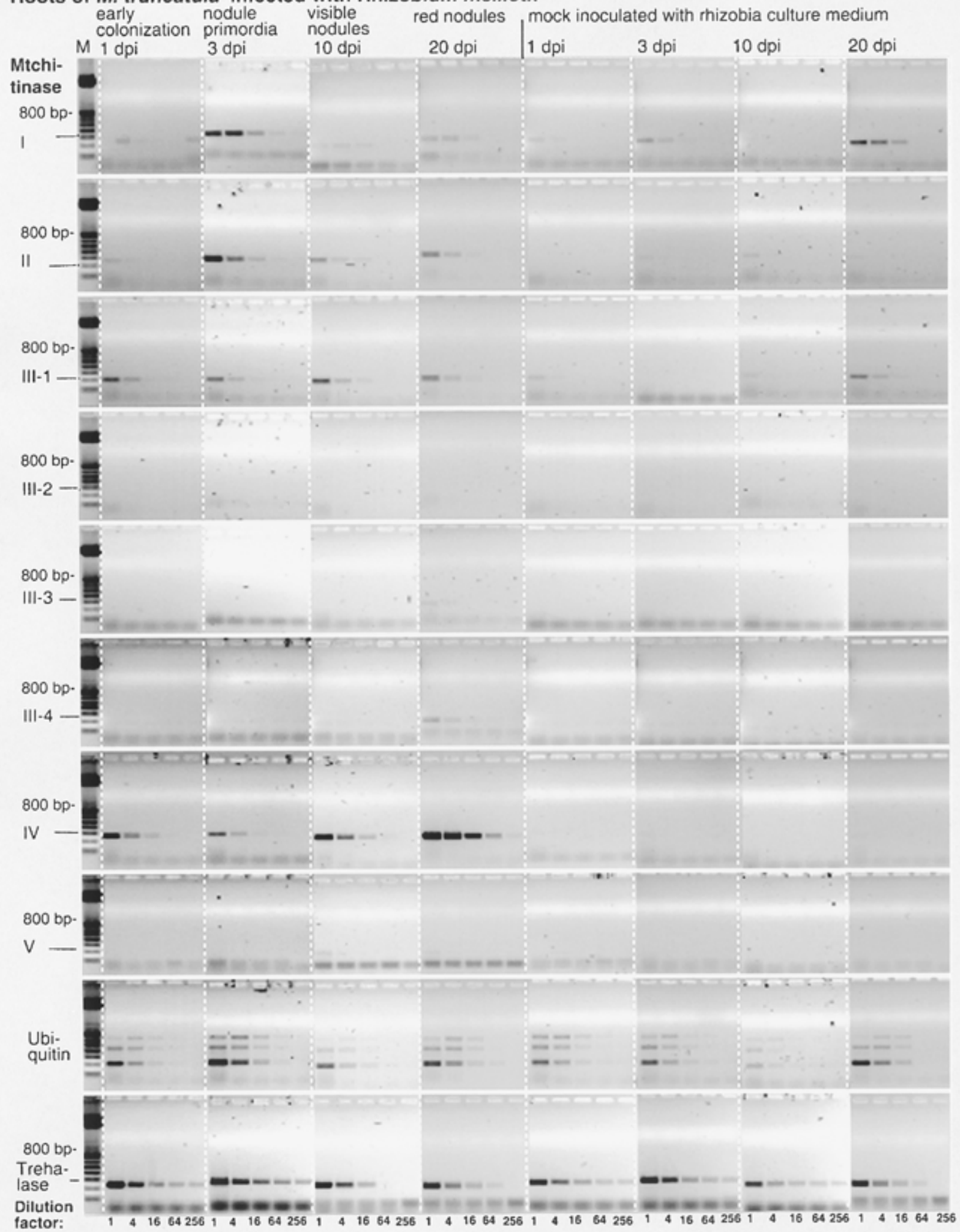

Fig. 6. Biphasic induction of chitinase genes during nodulation with Rhizobium meliloti. Semiquantitative reverse transcription-polymerase chain reaction (RT-PCR) performed with a dilution series of cDNA obtained from roots of Medicago truncatula inoculated with $R$. meliloti and from control roots mock inoculated with bacterial culture medium. For the time points 10 and 20 days, root sectors have been selected that harbored 15 to 30 nodules per $\mathrm{cm}$ of root length. Mtchitinase I and II were transiently increased during early stages, expression of Mtchitinase IV was most induced in mature nodules. Similar results were obtained in two independent experimental series. A 100-bp ladder was used as marker (M). 


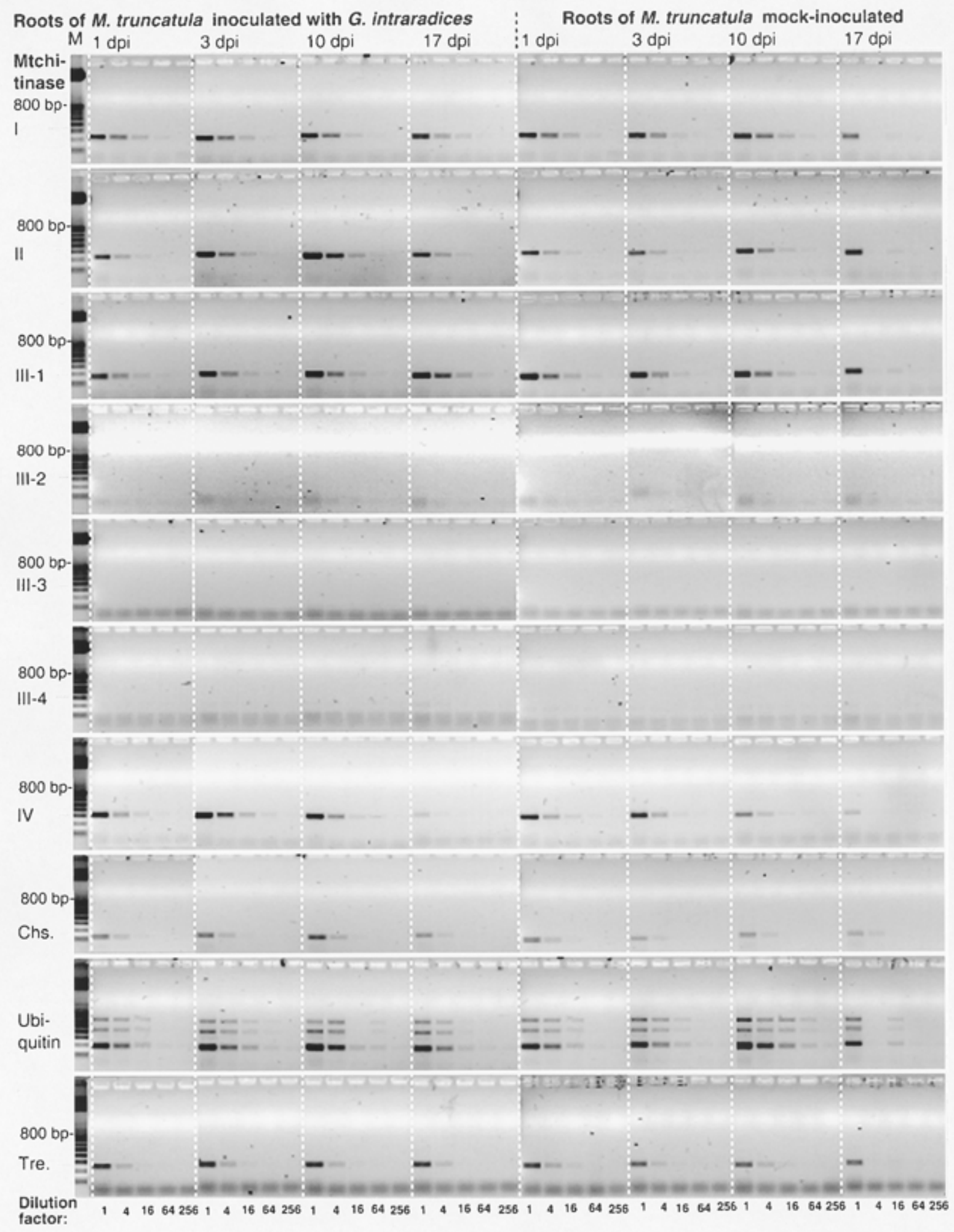

Fig. 7. Chitinase gene expression during early stages of mycorrhiza formation. Semiquantitative reverse transcription-polymerase chain reaction (RTPCR) performed with a dilution series of cDNA obtained from RNA extracted from seedlings of Medicago truncatula that have been inoculated with spores (five per root) and hyphae from $G$. intraradices. Three days after inoculation there was no physical contact between germinated spores and roots established. First internal hyphae, but no arbuscules and vesicles, were observed 10 days after inoculation. Internal hyphae and a few arbuscules but no vesicles were found at day 17 after inoculation. Expression of Mtchitinase II, III-1, and IV as well as of the chalcone synthase (Chs.) gene is already slightly induced before arbuscules were formed. In contrast, expression of Mtchitinase III-2, III-3, and III-4 could not be detected during the early stages of colonization. Similar results were obtained in two independent experimental series. A 100-bp ladder was used as marker (M). 
$\mu \mathrm{l}$ of Taq DNA polymerase (0.5 U; Amersham Pharmacia), $11.3 \mu \mathrm{l}$ of water, $2 \mu \mathrm{l}$ of forward primers $(2.5 \mu \mathrm{M})$ and $2 \mu \mathrm{l}$ of backward primers $(2.5 \mu \mathrm{M})$. The primer sequences and annealing temperatures are summarized in Table 3. Before cycling, samples were incubated at $95^{\circ} \mathrm{C}$ for $2 \mathrm{~min}$, followed by 28 cycles $\left(55^{\circ} \mathrm{C}, 30 \mathrm{~s} ; 72^{\circ} \mathrm{C}, 40 \mathrm{~s} ; 95^{\circ} \mathrm{C}, 15 \mathrm{~s}\right.$; and a final extension at $72^{\circ} \mathrm{C}$ for $7 \mathrm{~min}$ ). Finally, the reaction was cooled to $4^{\circ} \mathrm{C}$ and stopped by addition of $5 \mu \mathrm{l}$ of DNA-loading buffer consisting of 50\% vol/vol glycerol, $100 \mathrm{mM}$ EDTA, pH 8.0, and $0.05 \%(\mathrm{wt} / \mathrm{vol})$ xylene cyanol.

PCR products were separated by electrophoresis on $1.8 \%$ agarose gels in Tris-acetic acid-EDTA (TAE) buffer containing $0.24 \mu \mathrm{g} \cdot \mathrm{ml}^{-1}$ ethidium bromide. Documentation of the gels occurred under UV-light with a Bioprint image documentation system (Vilber Lourmat, Marne La Vallée, France). Final assembly of the pictures was done with Adobe Photoshop 3.0 (Mountain View, CA) and Claris Draw (Apple Computer Corp.) on a Macintosh G3.

DNA was isolated from axenically grown $M$. truncatula roots and fungi after homogenization in liquid nitrogen with a Nucleon Phytopure Plant DNA Extraction Kit (Amersham Pharmacia).

\section{Cloning chitinase and ubiquitin fragments from M. truncatula by PCR.}

Chitinase. Degenerate oligonucleotides were designed for five plant chitinase subclasses based on conserved amino acid motifs, as shown in Table 1 . To avoid size variation that would be introduced by intron sequences, conserved amino acid motifs were selected to reside within a single exon. The degenerate primer sets yielded amplified products of the expected sizes, as indicated in Table 1. Typical PCR conditions were 35 cycles, with a $45 \mathrm{~s}, 94^{\circ} \mathrm{C}$ denaturation step; a $30 \mathrm{~s}$, $55^{\circ} \mathrm{C}$ annealing step; and a $45 \mathrm{~s}, 72^{\circ} \mathrm{C}$ extension step. PCR products were cloned into $\mathrm{pPCR}$-Script-Amp vector (Stratagene, La Jolla, CA) and sequenced by means of a 377 DNA sequencer (Perkin Elmer Applied Biosystems, Foster City, CA).

Probes for Southern hybridization were prepared by digesting the PCR clones with the following enzyme combinations: Mtchitinase I, II, IV, and V, NotI and BamHI; Mtchitinase III1, BsgI and DdeI; Mtchitinase III-2, BsgI and DrdI; Mtchitinase III-3, NotI and DrdI, Mtchitinase III-4, BsgI and DrdI.

Ubiquitin. From genomic DNA of $M$. truncatula and $G$. mosseae ubiquitin fragments were amplified by PCR with the primers described for Vicia faba (Heidstra et al. 1997). The PCR fragments were cloned into the pCRTM Vector (Invitrogen, Leek, The Netherlands) and sequenced. Sequence

Fig. 8. Induction of chitinase class III-2, III-3, and III-4 gene expression in arbuscular mycorrhiza (AM) formed by Glomus intraradices on Medicago truncatula roots. Semiquantitative reverse transcriptionpolymerase chain reaction (RT-PCR) performed with a dilution series of cDNA obtained from $M$. truncatula roots colonized (about $60 \%$ of the root length with arbuscules, vesicles, or intraradical hyphae 5 weeks after inoculation) and noncolonized with $G$. intraradices. Only in mycorrhizal roots is expression of Mtchitinase III-2, III-3, and III-4 induced. Induction of Mtchitinase III-2 and III-3 is specific for a functioning mycorrhiza. The same results were obtained in at least three independent experimental series. A 100-bp ladder was used as marker (M). analysis was performed with the GCG software package (Genetics Computer Group, Madison, WI).

Primers for ITS1 and ITS4 specific for Fusarium solani were used according to J. Lange (unpublished). The primers




Table 2. Chitinase activity and gene expression induced in plants by microorganisms and their elicitors

\begin{tabular}{|c|c|c|c|c|}
\hline Plant species & & Microorganism $^{a}$ & Chitinases induced & References \\
\hline Allium porrum & $\mathrm{AM}$ & Glomus mosseae & Activity, transiently increased, roots & Spanu et al. 1989 \\
\hline Brassica campestris & $\mathrm{P}$ & Plasmodiophora brassicae & Activity, in roots & Ludwig-Müller et al. 1994 \\
\hline Cucumis melo & $\mathrm{P}$ & Colletotrichum lagenarium & Immuno detection, seedlings & Roby and Esquerre-Tugaye 1987 \\
\hline Сucurbita pepo & $\mathrm{P}$ & C. lagenarium & Class III mRNA, etiolated hypocotyls & Kästner et al. 1998 \\
\hline \multirow{2}{*}{ Eucalyptus globulus } & $\mathrm{P}$ & Phytophthora cinnamomi & Activity in gels increased, roots & Albrecht et al. 1994 \\
\hline & EM & Pisolithus tinctorius & New band in activity gels, roots & Albrecht et al. 1994 \\
\hline \multirow[t]{5}{*}{ Glycine max } & $\mathrm{R}$ & Bradyrhizobium japonicum & Activity, roots & Staehelin et al. 1992 \\
\hline & $\mathrm{R}$ & B. japonicum exo B mutant & Activity, nodules & Parniske et al. 1994 \\
\hline & $\mathrm{AM}$ & Glomus mosseae & Activity gels, roots & Xie et al. 1999 \\
\hline & $\mathrm{R}$ & B. japonicum & Activity gels, nodules & Xie et al. 1999 \\
\hline & $\mathrm{R}$ & Rhizobium sp. strain NGR234 & Activity gels, nodules & Xie et al. 1999 \\
\hline Hordeum vulgare & $\mathrm{P}$ & Erysiphe graminis f. sp. hordei & $\begin{array}{l}\text { Immuno detection, class II protein, } \\
\text { leaves }\end{array}$ & Ignatius et al. 1994; Kragh et al. 1997 \\
\hline Lycopersicon esculentum & $\mathrm{P}$ & Cladosporium fulvum & Activity, leaves & Joosten and De Wit 1989 \\
\hline \multirow{2}{*}{ Medicago sativa } & $\mathrm{AM}$ & Glomus intraradices & Activity, roots & Volpin et al. 1994 \\
\hline & $\mathrm{R}$ & Rhizobium meliloti & $\begin{array}{l}\text { PR-P, PR-Q, class II, cortical root } \\
\text { cells }\end{array}$ & Vasse et al. 1993 \\
\hline \multirow[t]{7}{*}{ Medicago truncatula } & $\mathrm{AM}$ & G. intraradices & Class III-2, III-3, III-4, mRNA, roots & This study \\
\hline & $\mathrm{P}$ & Ascochyta pisi & Class I, II, III-1, III-4, mRNA, roots & This study \\
\hline & $\mathrm{P}$ & Fusarium solani f. sp. phaseoli & Class I, II, III-1, IV, mRNA, roots & This study \\
\hline & $\mathrm{P}$ & F. solani f. sp. pisi & Class I, III-4, IV, mRNA, roots & This study \\
\hline & $\mathrm{P}$ & $\begin{array}{l}\text { Phytophthora megasperma f. sp. } \\
\text { medicaginis }\end{array}$ & Class I, II, III-1, IV, mRNA, roots & This study \\
\hline & $\mathrm{R}$ & R. meliloti & Class I, II, mRNA, transient, roots & This study \\
\hline & $\mathrm{R}$ & R. meliloti & Class IV, III-4, mRNA, nodules & This study \\
\hline \multirow[t]{9}{*}{ Nicotiana tabacum } & $\mathrm{AM}$ & Glomus versiforme & Acidic chitinase, activity gels, roots & Dumas-Gaudot et al. 1992 \\
\hline & AM & G. intraradices & Acidic chitinase, activity gels, roots & Dumas-Gaudot et al. 1992 \\
\hline & $\mathrm{AM}$ & Glomus fasciculatum & Acidic chitinase, activity gels, roots & Dumas-Gaudot et al. 1992 \\
\hline & $\mathrm{P}$ & Chalara elegans & Acidic chitinase, activity gels, roots & Dumas-Gaudot et al. 1992 \\
\hline & $\mathrm{P}$ & Tobacco mosaic virus & $\begin{array}{l}\text { PR-P, PR-Q equivalent to class II, } \\
\text { leaves }\end{array}$ & Payne et al. 1990 \\
\hline & $\mathrm{P}$ & Tobacco mosaic virus & Acidic and basic class III, leaves & Lawton et al. 1992 \\
\hline & $\mathrm{P}$ & Phytophthora infestans (elicitor) & $\begin{array}{l}\text { Class I basic, class II acidic, mRNA, } \\
\text { cells }\end{array}$ & Suzuki et al. 1995 \\
\hline & $\mathrm{P}$ & Phytophthora parasitica & Class I basic, mRNA, leaves & Meins and Ahl 1989 \\
\hline & $\mathrm{P}$ & Pseudomonas tabaci & Class I basic, mRNA, leaves & Meins and Ahl 1989 \\
\hline Oryza sativa & $\mathrm{P}$ & Rhizoctonia solani & $35 \mathrm{kDa}, 28 \mathrm{kDa}$ protein, sheath & Anuratha et al. 1996 \\
\hline \multirow{4}{*}{ Phaseolus vulgaris } & $\mathrm{AM}$ & G. intraradices & Activity, class I, and II, mRNA, roots & Lambais and Mehdy 1993 \\
\hline & $\mathrm{AM}$ & G. intraradices & $\begin{array}{l}\text { mRNA (in situ) in cells with arbus- } \\
\text { cules }\end{array}$ & Blee and Anderson 1996 \\
\hline & $\mathrm{P}$ & F. solani f. sp. phaseoli & Class I, II, IV mRNA, roots & Mohr et al. 1998; Lange et al. 1996 \\
\hline & $\mathrm{P}$ & $\begin{array}{l}\text { Colletotrichum lindemuthianum, } \\
\text { fungus and elicitors }\end{array}$ & mRNA, hypocotyl and cells & Hedrick et al. 1988 \\
\hline \multirow[t]{2}{*}{ Picea abies } & EM & Amanita muscaria, elicitors & Activity, cells & Sauter and Hager 1989 \\
\hline & EM & Hebeloma crustuliniforme & Activity gels, roots & Salzer et al. 1997b \\
\hline \multirow[t]{2}{*}{ Pisum sativum } & AM & G. mosseae & Acidic chitinase, activity gel, roots & Dumas-Gaudot et al. 1994 \\
\hline & $\mathrm{P}$ & A. pisi & Class I mRNA, leaves & Vad et al. 1993 \\
\hline Sesbania rostrata & $\mathrm{R}$ & Azorhizobium caulinodans & Srchi13, homolog to class III, stem & Goormachtig et al. 1998 \\
\hline Solanum tuberosum & $\mathrm{P}$ & $\begin{array}{l}\text { Phytophthora infestans fungus } \\
\text { and elicitors }\end{array}$ & Class I, II mRNA, leaves & Büchter et al. 1997 \\
\hline Triticum aestivum & $P$ & Puccinia graminis f. sp. tritici & Class I, mRNA, leaves & $\begin{array}{l}\text { Liao et al. 1994; Münch-Garthoff et } \\
\quad \text { al. } 1997\end{array}$ \\
\hline Vicia faba & $\mathrm{R}$ & $\begin{array}{l}\text { Rhizobium leguminosarum bv. } \\
\text { viciae }\end{array}$ & $\begin{array}{l}\text { Nvf32-A1, Nvf32-A2, homology to } \\
\text { class III chitinase proteins, roots }\end{array}$ & Perlick et al. 1996 \\
\hline
\end{tabular}

${ }^{\mathrm{a}} \mathrm{P}=$ pathogens, $\mathrm{AM}=$ arbuscular mycorrhizae, $\mathrm{EM}=$ ectomycorrhizae, $\mathrm{R}=$ rhizobia.

used to amplify ITS1 and ITS4 in M. truncatula, G. intraradices, Ascochyta pisi, and Phytophthora megasperma f. sp. medicaginis were described by Heidstra et al. (1997).

Chalcone synthase. Primers for chalcone synthase were designed after cloning and sequencing a cDNA band that was detected by differential display to be induced in mycorrhizal roots of M. truncatula (Vögeli-Lange et al. 1996).

Trehalase. From genomic DNA of M. truncatula, a PCR fragment was amplified with degenerate primers mapping to conserved regions of a trehalase gene in Glycine max (Aeschbacher et al. 1999). Cloning and sequencing of this fragment revealed that it contained an intron. For RT-PCR, the forward primer was positioned upstream and the reversed primer downstream of the intron.

The sequences of the chitinase gene fragments were deposited in the National Center for Biotechnology Information (NCBI) Genome Survey Sequence data base (GSSdb) with the following accession numbers: Mtchitinase I, AF167322; Mtchitinase II, AF167323; Mtchitinase III-1, AF167324; Mtchitinase III-2, AF167325; Mtchitinase III-3, AF167326; Mtchitinase III-4, AF167327; Mtchitinase IV, AF167328, and Mtchitinase V, AF167329. Sequence data for trehalase and 


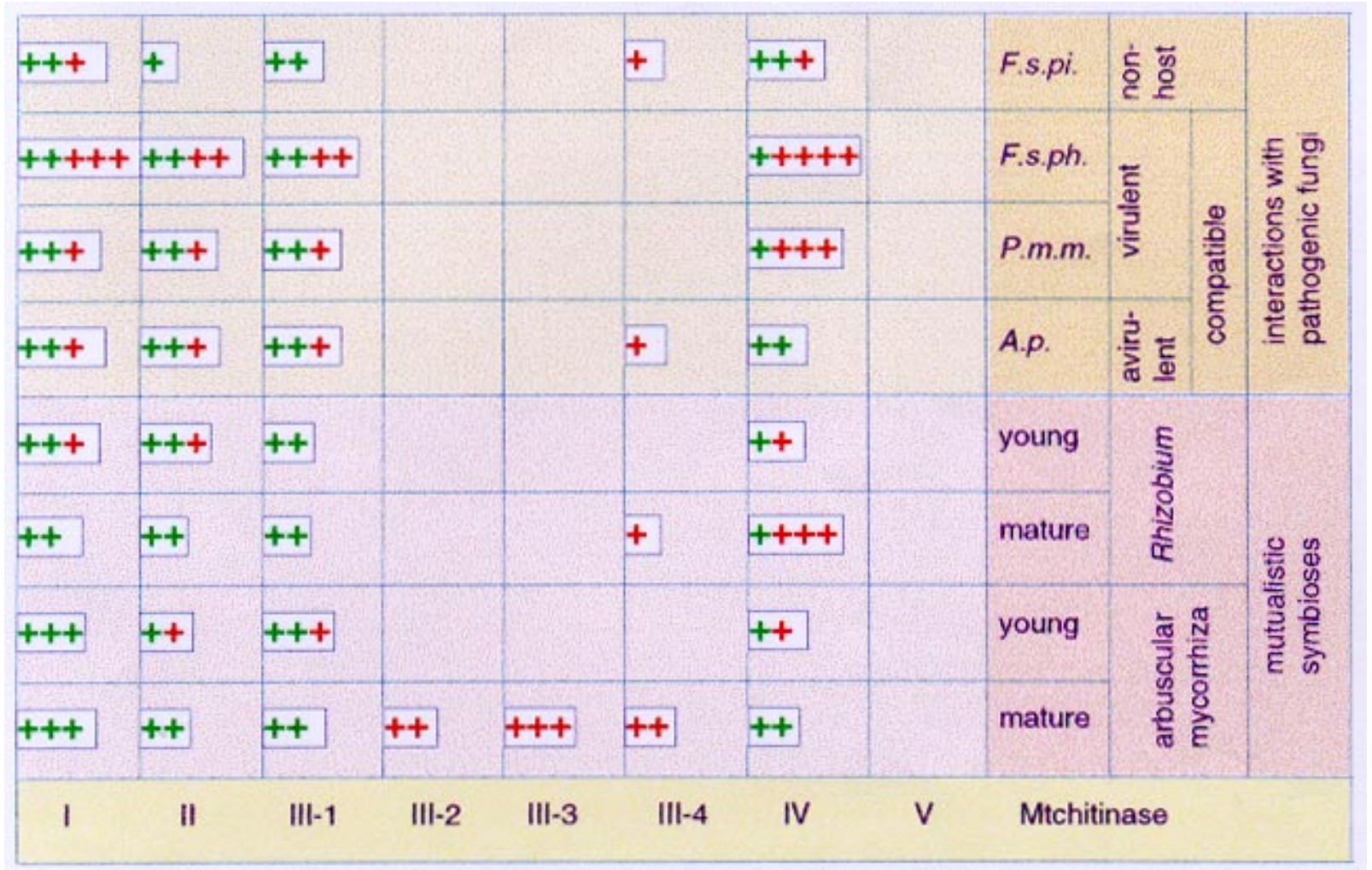

Fig. 9. Comprehensive survey of Mtchitinase expression in roots of Medicago truncatula infected with rhizobia and mycorrhizal and pathogenic fungi. Total number of crosses (green plus red) resembles level of gene expression of a certain Mtchitinase. Red symbols highlight level of expression, which is due to induction by the microorganism. Green symbols give expression level in corresponding axenic control roots. For mutualistic symbioses, the strongest expression level at an early (young) or later stage (mature) of the interaction is shown. Number of crosses corresponds to average number of bands detected in dilution series of two independent experimental series. Half numbers are rounded off and shown as a cross.

Table 3. Primer sequences used for reverse transcription-polymerase chain reaction $^{\mathrm{a}}$

\begin{tabular}{|c|c|c|}
\hline Mtchitinase & Primer sequence & Tm \\
\hline I & $\begin{array}{l}\text { (f) 5'-TCAACCGGCGACTACTGTGGTGATG-3' } \\
\text { (b) 5'-CCCAAGAAAGCAGCAATCTCTC-3' }\end{array}$ & \\
\hline II & $\begin{array}{l}\text { (f) 5'-CCCAACTGTATCATTCAAGACAGCC-3' } \\
\text { (b) 5'-CACCAGGACTCACTCCCAATATTTGA } \\
\text { C-3' }\end{array}$ & \\
\hline
\end{tabular}

III-1 (f) $5^{\prime}$-CCCTGGTGCTTGTAACTTTGTTTC- $3^{\prime} \quad 64.5^{\circ} \mathrm{C}$

(b) $5^{\prime}$-GGTGAAGGCTTAACAATAGGCAGC-3' $65.6^{\circ} \mathrm{C}$

III-2 (f) $5^{\prime}$-CCTGAATGTGACTATAGTGAAAGCGA $64.6^{\circ} \mathrm{C}$ G-3'

III-3 (f) $5^{\prime}$-CCTTGTCAATACAATCCTGGTG-3' $33.4^{\circ} \mathrm{C}$

$\begin{array}{ll}\text { (b) } 5^{\prime} \text {-GCAGAACCTTTAATAGCTGG-3' } & 62.6^{\circ} \mathrm{C}\end{array}$

III-4 (f) $5^{\prime}$-CCCTGATGCATTTATGAAC-3' $\quad 61.1^{\circ} \mathrm{C}$

(b) 5'-CCGTCTTTGGAAGAACCTTTAATAACT $64.8^{\circ} \mathrm{C}$ GG-3'

IV (f) $5^{\prime}$-GGTGATGCATATTGTGGCACAGGG-3' $66.6^{\circ} \mathrm{C}$

(b) 5'-GCAGCAGCAACCTCACGTTTGGAG-3' $67.4^{\circ} \mathrm{C}$

$\mathrm{V} \quad$ (f) $5^{\prime}$-AAGAGTTGGAAGCTTCAGGATCCG-3' $65.6^{\circ} \mathrm{C}$

(b) $5^{\prime}$-CCCACTATATGAATAAACCGATCCGG- $65.3^{\circ} \mathrm{C}$

MtUbiquitin (f) $5^{\prime}$-GTGAAGACCTTGACCGGCAAAAC- $3^{\prime} \quad 61.9^{\circ} \mathrm{C}$ (b) 5'-GGTGAAGCGTGGACTCTTTCTGG-3' $63.5^{\circ} \mathrm{C}$

MtTrehalase (f) $5^{\prime}$-CGGTTGGGCTCCACTTCAACAC- $3^{\prime} \quad 62.1^{\circ} \mathrm{C}$

(b) 5'-GGACCATCCAAAWCCSGTCTG-3' $59.0^{\circ} \mathrm{C}$

Chalcone (f) $5^{\prime}$-CGAAAAGATGAATGCAAC- $3^{\prime} \quad 47.5^{\circ} \mathrm{C}$

synthase (b) 5'-CCAAAACCAAATAACACAC-3' $48.4^{\circ} \mathrm{C}$

${ }^{a} \mathrm{Tm}$ gives annealing temperature, (f) designates forward and (b) backward orientation of primers. In the degenerate primers $\mathrm{W}$ stands for $\mathrm{A}$ and $\mathrm{T}, \mathrm{S}$ for $\mathrm{G}$ and $\mathrm{C}$. ubiquitin were deposited in the European Molecular Biology Laboratories (EMBL) gene bank and are available by accession number AJ238651 for the trehalase gene, AJ245511 for the ubiquitin gene fragment of Medicago truncatula, and $\mathrm{AJ} 245512$ for the ubiquitin gene fragment of Glomus mosseae.

\section{ACKNOWLEDGMENTS}

This work was supported by grants of the Swiss National Science Foundation to T. B., R. V.-L., and A. W.; P. S. was supported by a Habilitanden Stipendium from the Deutsche Forschungsgemeinschaft. We want to thank our colleagues from the Botanical Institute in Basel for their help, especially M. Alt and N. Bürckert for cloning and sequencing ubiquitin from G. mosseae, and H. Corbière for her support in culturing G. intraradices. We also thank U. Gisi and R. Gees (Novartis, Stein, Switzerland) for their help in identifying fungal structures.

\section{LITERATURE CITED}

Aeschbacher, R. A., Müller, J., Boller, T., and Wiemken, A. 1999. Purification of the trehalose GMTRE1 from soybean nodules and cloning of its cDNA. GMTRE1 is expressed at a low level in multiple tissues. Plant Physiol. 119:489-495.

Albrecht, C., Asselin, A., Piché, Y., and Lapeyrie, F. 1994. Chitinase activities are induced in Eucalyptus globulus roots by ectomycorrhizal or pathogenic fungi during early colonisation. Physiol. Plant. 91:104-110.

Albrecht, C., Guerts, R., Lapeyrie, F., and Bisseling, T. 1998. Endomycorrizae and rhizobial Nod factors both require SYM8 to induce expression of the early nodulin genes PsENOD5 and PsENOD12A. Plant J. 15:605-614. 
Anuratha, C. S., Zen, K. C., Cole, K. C., Mew, T., and Muthukrishnan, S. 1996. Induction of chitinases and $\beta$-1,3-glucanases in Rhizoctonia solani-infected rice plants: Isolation of an infection-related chitinase cDNA clone. Physiol. Plant. 97:39-46.

Arlorio, M., Ludwig, A., Boller, T., and Bonfante, P. 1992. Inhibition of fungal growth by plant chitinases and $\beta-1,3$-glucanases. Protoplasma 171:34-43.

Arlorio, M., Ludwig, A., Boller, T., Mischiati, P., and Bonfante, P. 1991. Effects of chitinase and $\beta$-1,3-glucanase from pea on the growth of saprophytic, pathogenic and mycorrhizal fungi. Giorn. Bot. Ital. 125: 956-959.

Blee, K. A., and Anderson, A. J. 1996. Defense-related transcript accumulation in Phaseolus vulgaris L. colonized by the arbuscular mycorrhizal fungus Glomus intraradices Schenk \& Smith. Plant Physiol. 110:675-688.

Boller, T. 1987. Hydrolytic enzymes in plant disease resistance. Pages 385-413 in: Plant-Microbe Interactions Volume 2. T. Kosuge and E. W. Nester, eds. Macmillan, New York.

Broglie, K., Chet, I., Holliday, M., Cressman, R., Biddle, P., Knowlton, S., Mauvais, C. J., and Broglie, R. 1991. Transgenic plants with enhanced resistance to the fungal pathogen Rhizoctonia solani. Science 254:1194-1197.

Broughton, W., and John, C. 1979. Rhizobia in tropical legumes III. Experimentation and supply in Malaysia 1927-1976. Pages 113-136 in: Soil Microbiology and Plant Nutrition. W. Broughton, C. John, B. Lim, and C. Rajova, eds. University of Malaysia Press, Kuala Lumpur, Malaysia.

Büchter, R., Strömberg, A., Schmelzer, E., and Kombrink, E. 1997. Primary structure and expression of acidic (class II) chitinase in potato. Plant. Mol. Biol. 35:749-761.

Chen, Q. G., and Bleeker, A. B. 1995. Analysis of ethylene signal transduction kinetics associated with seedling-growth response and chitinase induction in wild-type and mutant Arabidopsis. Plant Physiol. 108:597-607.

Collinge, D. B., Kragh, K. M., Mikkelsen, J. D., Nielsen, K. K., Rasmussen, U., and Vad, K. 1993. Plant chitinases. Plant J. 3:31-40.

Cook, D. 1999. Medicago truncatula - A model in the making! Curr. Opin. Plant Biol. 2:301-304.

Cook, D., Dreyer, D., Bonnet, D., Howell, M., Nony, E., and Vanden Bosch, K. 1995. Transient induction of a peroxidase gene in Medicago truncatula precedes infection by Rhizobium meliloti. Plant Cell 7:43-55.

Cook, D., Vanden Bosch, K., de Bruijn, F., and Huguet, T. 1997. Model legumes get the nod. Plant Cell 9:275-281.

David, R., Itzhaki, H., Ginzberg, I., Gafni, Y., Galili, G., and Kapulnik, Y. 1998. Suppression of tobacco basic chitinase gene expression in response to colonization by the arbuscular mycorrhizal fungus Glomus intraradices. Mol. Plant-Microbe Interact. 11:489-497.

Dumas-Gaudot, E., Asselin, A., Gianinazzi-Pearson, V., Gollotte, A., and Gianinazzi, S. 1994. Chitinase isoforms in roots of various pea genotypes infected with arbuscular mycorrhizal fungi. Plant Sci. 99: 27-37.

Dumas-Gaudot, E., Furlan, V., Grenier, J., and Asselin, A. 1992. New acidic chitinase isoforms induced in tobacco roots by vesicular arbuscular mycorrhizal fungi. Mycorrhiza 1:133-136.

Felix, G., Regenass, M., and Boller, T. 1993. Specific perception of subnanomolar concentrations of chitin fragments by tomato cells: Induction of extracellular alkalinization, changes in protein phosphorylation, and establishment of a refractory state. Plant J. 4:307-316.

Frühling, M., Roussel, H., Gianinazzi-Pearson, V., Pühler, A., and Perlick, A. M. 1997. The Vicia faba leghemoglobin gene VfLb29 is induced in root nodules and in roots colonized by the arbuscular mycorrhizal fungus Glomus fasciculatum. Mol. Plant-Microbe Interact. 10:124-131.

Giovanetti, M., and Mosse, B. 1980. An evaluation of techniques for measuring vesicular arbuscular infection in roots. New Phytol. 84: 489-500.

Goormachtig, S., Lievens, S., Van de Velde, W., Van Montagu, M., and Holsters, M. 1998. Srchi13, a novel early nodulin from Sesbania rostrata, is related to acidic class III chitinases. Plant Cell 10:905-915.

Harrison, M. J., and Dixon, R. A. 1994. Spatial pattern of expression of flavonoid/isoflavonoid pathway genes during interactions between roots of Medicago truncatula and the mycorrhizal fungus Glomus versiforme. Plant J. 6:9-20.
Hebe, G., Hager, A., and Salzer, P. 1999. Initial signalling processes induced by elicitors of ectomycorrhiza-forming fungi in spruce cells can also be triggered by G-protein-activating mastoparan and protein phosphatase-inhibiting cantharidin. Planta 207:418-425.

Hedrick, S. A., Bell, J. N., Boller, T., and Lamb, C. J. 1988. Chitinase cDNA cloning and mRNA induction by fungal elicitor, wounding, and infection. Plant Physiol. 86:182-186.

Heidstra, R., Nilsen, G., Martinez-Abarca, F., van Kammen, A., and Bisseling, T. 1997. Nod factor-induced expression of leghemoglobin to study the mechanism of $\mathrm{NH}_{4} \mathrm{NO}_{3}$ inhibition on root hair deformation. Mol. Plant-Microbe Interact. 10:215-220.

Ignatius, S. M. J., Chopra, R. K., and Muthukrishnan, S. 1994. Effects of fungal infection and wounding on the expression of chitinases and $\beta$ 1,3-glucanases in near isogenic lines of barley. Physiol. Plant. 90:584592.

Inui, H., Yamaguchi, Y., and Hirano, S. 1997. Elicitor actions of Nacetylchitooligosaccharides and laminarioligosaccharides for chitinase and L-phenylalanine ammonia-lyase induction in rice suspension culture. Biosci. Biotechnol. Biochem. 61:975-978.

Inui, H., Yamaguchi, Y., Ishigami, Y., Kawaguchi, S., Yamada, T., Ihara, H., and Hirano, S. 1996. Three extracellular chitinases in suspensioncultured rice cells elicited by $N$-acetylchitooligosaccharides. Biosci. Biotechnol. Biochem. 60:1956-1961.

Joosten, M. H. A. J., and De Wit, P. J. G. M. 1989. Identification of several pathogenesis-related proteins in tomato leaves inoculated with Cladosporium fulvum (syn. Fulvia fulva) as $\beta-1,3$-glucanases and chitinases. Plant Physiol. 89:945-951.

Jung, J. L., Fritig, B., and Hahne, G. 1993. Sunflower (Helianthus annuus L.) pathogenesis-related proteins. Induction by aspirin (acetylsalicylic acid) and characterization. Plant Physiol. 101:873-880.

Kästner, B., Tenhaken, R., and Kauss, H. 1998. Chitinase in cucumber hypocotyls is induced by germinating fungal spores and by fungal elicitor in synergism with inducers of acquired resistance. Plant J. 13: 447-454.

Kragh, K. M., Jacobsen, S., and Mikkelsen, J. D. 1990. Induction, purification and characterization of barley leaf chitinase. Plant Sci. 71:5568.

Lambais, M. R., and Mehdy, M. C. 1993. Suppression of endochitinase, $\beta-1,3$-endoglucanase, and chalcone isomerase expression in bean vesicular-arbuscular mycorrhizal roots under different soil phosphate conditions. Mol. Plant-Microbe Interact. 6:75-83.

Lange, J., Mohr, U., Wiemken, A., Boller, T., and Vögeli-Lange, R. 1996. Proteolytic processing of class IV chitinase in the compatible interaction of bean roots with Fusarium solani. Plant Physiol. 111:135-1144.

Lawton, K., Ward, E., Payne, G., Moyer, M., and Ryals, J. 1992. Acidic and basic class III chitinase mRNA accumulation in response to TMV infection of tobacco. Plant Mol. Biol. 19:735-743.

Levorson, J., and Chlan, C. A. 1997. Plant chitinase consensus sequences. Plant Mol. Biol. Rep. 15:122-133.

Liao, Y. C., Kreuzaler, F., Fischer, R., Reisner, H. J., and Tiburzy, R. 1994. Characterization of a wheat class Ib chitinase gene differentially induced in isogenic lines by infection with Puccinia graminis. Plant Sci. 103:177-187.

Ludwig-Müller, J., Thermann, P., Pieper, K., and Hilgenberg, W. 1994. Peroxidase and chitinase isoenzyme activities during root infection of Chinese cabbage with Plasmodiophora brassicae. Physiol. Plant. 90: 661-670.

Margis-Pinheiro, M., Marivet, J., and Burkard, G. 1994. Bean class IV chitinase gene: Structure, developmental expression and induction by heat stress. Plant Sci. 98:163-173.

Mauch, F., Mauch-Mani, B., and Boller, T. 1988. Antifungal hydrolases in pea tissue. II. Inhibition of fungal growth by combinations of chitinase and $\beta$-1,3-glucanase. Plant Physiol. 88:936-942.

Meins, F., Jr., and Ahl, P. 1989. Induction of chitinase and $\beta-1,3-$ glucanase in tobacco plants infected with Pseudomonas tabaci and Phytophthora parasitica var. nicotianae. Plant Sci. 61:155-161.

Meins, F., Jr., Fritig, B., Linthorst, H. J. M., Mikkelsen, J. D., Neuhaus, J. M., and Ryals, J. 1994. Plant chitinase genes. Plant Mol. Biol. Rep. $12: 22-28$

Meins, F., Jr., Neuhaus, J. M., Sperisen, C., and Ryals, J. 1992. The primary structure of plant pathogenesis related glucanohydrolases and their genes. Pages 245-282 in: Genes Involved in Plant Defense. T. Boller and F. Meins, Jr., eds. Springer, Vienna. 
Melchers, L. S., Apotheker-de Groot, M., van der Knaap, J. A., Ponstein, A. S., Sela-Buurlage, M. S., Bol, J. F., Cornelissen, B. J. C., van den Elzen, P. J. M., and Linthorst, H. J. M. 1994. A new class of tobacco chitinases homologous to bacterial exo-chitinases displays antifungal activity. Plant J. 5:469-480.

Mohr, U., Lange, J., Boller, T., Wiemken, A., and Vögeli-Lange, R. 1998. Plant defense genes are induced in the pathogenic interaction between bean roots and Fusarium solani, but not in the symbiotic interaction with the arbuscular mycorrhizal fungus Glomus mosseae. New Phytol. 138:589-598.

Münch-Garthoff, S., Neuhaus, J. M., Boller, T., Kemmerling, B., and Kogel, K. H. 1997. Expression of $\beta$-1,3-glucanase and chitinase in healthy, stem-rust-affected and elicitor-treated near-isogenic wheat lines showing Sr5-or Sr24-specified race-specific rust resistance. Planta 201:235-244.

Nam, Y. W., Penmetsa, R. V., Endre, G., Kim, D., and Cook, D. R. 1999. Construction of a bacterial artificial chromosome library of Medicago truncatula and identification of clones containing ethylene response genes. Theor. Appl. Genet. 98:638-646.

Ohme-Takagi, M., Meins, F., Jr., and Shinshi, H. 1998. A tobacco gene encoding a novel basic class II chitinase: A putative ancestor of basic class I and acidic class II chitinase genes. Mol. Gen. Genet. 259:511515.

Parniske, M., Schmidt, P. E., Kosch, K., and Müller, P. 1994. Plant defense responses of host plants with determinate nodules induced by EPS-defective exoB mutants of Bradyrhizobium japonicum. Mol. Plant-Microbe Interact. 7:631-638.

Payne, G., Ahl, P., Moyer, M., Harper, A., Beck, J., Meins, F., Jr., and Ryals, J. 1990. Isolation of complementary DNA clones encoding pathogenesis-related proteins $\mathrm{P}$ and $\mathrm{Q}$, two acidic chitinases from tobacco. Proc. Natl. Acad. Sci. USA 87:98-102.

Perlick, A. M., Frühling, M., Schröder, G., Frosch, S. C., and Pühler, A. 1996. The broad bean gene VfNOD32 encodes a nodulin with sequence similarities to chitinases that is homologous to $(\alpha / \beta)$-barreltype seed proteins. Plant Physiol. 110:147-154.

Phillips, J. M., and Hayman, D. S. 1970. Improved procedures for clearing roots and staining parasitic and vesicular-arbuscular mycorrhizal fungi for rapid assessment of infection. Transact. Br. Mycol. Soc. 55:158-160.

Roby, D., and Esquerre-Tugaye, M. T. 1987. Induction of chitinases and translatable mRNA for these enzymes in melon plants infected with Colletotrichum lagenarium. Plant Sci. 52:175-185.

Salzer, P., and Boller, T. 2000. Elicitor-induced reactions in mycorrhizae and their suppression. Pages 1-10 in: Current Advances in Mycorrhizae Research. G. K. Podila and D. D. Douds, Jr., eds. American Phytopathological Society, St. Paul, MN.

Salzer, P., Corbiére, H., and Boller, T. 1999. Hydrogen peroxide accumulation in Medicago truncatula roots colonized by the arbuscular mycorrhiza-forming fungus Glomus intraradices. Planta 208:319-325.

Salzer, P., Hebe, G., and Hager, A. 1997a. Cleavage of chitinous elicitors from the ectomycorrhizal fungus Hebeloma crustuliniforme by host chitinases prevents induction of $\mathrm{K}^{+}$and $\mathrm{Cl}^{-}$release, extracellular alkalinization and $\mathrm{H}_{2} \mathrm{O}_{2}$ synthesis of Picea abies cells. Planta 203: 470479.

Salzer, P., Hübner, B., Sirrenberg, A., and Hager, A. 1997b. Differential effect of purified spruce chitinases and $\beta$-1,3-glucanases on the activity of elicitors from ectomycorrhizal fungi. Plant Physiol. 114:957968.

Sauter, M., and Hager, A. 1989. The mycorrhizal fungus Amanita muscaria induces chitinase activity in roots and in suspension-cultured cells of its host Picea abies. Planta 179:61-66.

Savouré, A., Sallaud, C., El-Turk, J., Zuanazzi, J., Ratet, P., Schultze, M., Kondorosi, A., Esnault, R., and Kondorosi, E. 1997. Distinct response of Medicago suspension cultures and roots to Nod factors and chitin oligomers in the elicitation of defense-related responses. Plant J. 11:277-287.
Schlumbaum, A., Mauch, F., Vögeli, U., and Boller, T. 1986. Plant chitinases are potent inhibitors of fungal growth. Nature 324:365-367.

Schmidt, P. E., Parniske, M., and Werner, D. 1992. Production of the phytoalexin glyceollin I by soybean roots in response to symbiotic and pathogenic infection. Bot. Acta 105:18-25.

Schultze, M., Staehelin, C., Brunner, F., Genetet, I., Legrand, M., Fritig, B., Kondorosi, E., and Kondorosi, A. 1998. Plant chitinase/lysozyme isoforms show distinct substrate specificity and cleavage site preference towards lipochitooligosaccharide Nod signals. Plant J. 16:571580.

Shinshi, H., Usami, S., and Ohme-Takagi, M. 1995. Identification of an ethylene-responsive region in the promoter of a tobacco class I chitinase gene. Plant Mol. Biol. 27:923-932.

Siefert, F., Langenbartels, C., Boller, T., and Grossmann, K. 1994. Are ethylene and 1-aminocyclopropane-1-carboxylic acid involved in the induction of chitinase and $\beta$-1,3-glucanase activity in sunflower cellsuspension cultures? Planta 192:431-440.

Spanu, P., Boller, T., Ludwig, A., Wiemken, A., and Faccio, A. 1989. Chitinase in roots of mycorrhizal Allium porrum: Regulation and localization. Planta 177:447-455.

Staehelin, C., Granado, J., Müller, J., Wiemken, A., Mellor, R.G., Felix, G., Regenass, M., Broughton, W. J., and Boller, T. 1994a. Perception of Rhizobium nodulation factors by tomato cells and inactivation by root chitinases. Proc. Natl. Acad. Sci. USA 91:2196-2200.

Staehelin, C., Müller, J., Mellor, R. B., Wiemken, A., and Boller, T. 1992. Chitinase and peroxidase in effective $\left(\mathrm{fix}^{+}\right)$and ineffective $\left(\mathrm{fix}^{-}\right)$soybean nodules. Planta 187:295-300.

Staehelin, C., Schultze, M., Kondorosi, E., Mellor, R. B., Boller, T., and Kondorosi, A. 1994b. Structural modifications in Rhizobium meliloti Nod factors influence their stability against hydrolysis by root chitinases. Plant J. 5:319-330.

Suzuki, K., Fukuda, Y., and Shinshi, H. 1995. Studies on elicitor-signal transduction leading to differential expression of defense genes in cultured tobacco cells. Plant Cell Physiol. 36:281-289.

Vad, K., de Neergaard, E., Madriz-Ordenena, K., Mikkelsen, J. D., and Collinge, D. B. 1993. Accumulation of defense-related transcripts and cloning of a chitinase mRNA from pea leaves (Pisum sativum L.) inoculated with Ascochyta pisi Lib. Plant Sci. 92:69-79.

Vasse, J., de Billy, F., and Truchet, G. 1993. Abortion of infection during the Rhizobium meliloti-alfalfa symbiotic interaction is accompanied by a hypersensitive reaction. Plant J. 4:555-566.

Vierheilig, H., Alt, M., Neuhaus, J.-M., Boller, T., and Wiemken, A. 1993. Colonization of transgenic Nicotiana sylvestris plants, expressing different forms of Nicotiana tabacum chitinase, by the root pathogen Rhizoctonia solani and by the mycorrhizal symbiont Glomus mosseae. Mol. Plant-Microbe Interact. 6:261-264.

Vögeli-Lange, R., Bürckert, N., Boller, T., and Wiemken, A. 1996. Rapid selection and classification of positive clones generated by mRNA differential display. Nucleic Acids Res. 24:1385-1386.

Vögeli-Lange, R., Mohr, U., Düggelin, M., Guggenheim, R., and Boller, T. 1995. Developmental regulation of susceptibility and tolerance to Fusarium root rot in beans. Bot. Acta 108:387-395.

Volpin, H., Elkind, Y., Okon, Y., and Kapulnik, Y. 1994. A vesicular arbuscular mycorrhizal fungus (Glomus intraradix) induces a defense response in alfalfa roots. Plant Physiol. 104:683-689.

Wyss, W., Mellor, R. B., and Wiemken, A. 1990. Vesicular-arbuscular mycorrhizas of wild-type soybean and non-nodulating mutants with Glomus mosseae contain symbiosis-specific polypeptides (mycorrhizins) immunologically cross-reactive with nodulins. Planta 182:2226.

Xie, Z. P., Staehelin, C., Wiemken, A., and Boller, T. 1996. Ethylene responsiveness of soybean cultivars characterised by leaf senescence, chitinase induction and nodulation. J. Plant Physiol. 149:690-694.

Xie, Z. P., Staehelin, C., Wiemken, A., Broughton, W. J., Müller, J., and Boller, T. 1999. Symbiosis-stimulated chitinase isoenzymes of soybean (Glycine max (L.) Merr.). J. Exp. Bot. 50:327-333. 